\title{
生体内含硫無機化合物の定量法並びにイオウ転移酵素の測定法の開発と,
} 結合型イオウの生理学的機能評価

\author{
田邊信三
}

\section{Development of Assay Methods for Endogenous Inorganic Sulfur Compounds and Sulfurtransferases and Evaluation of the Physiological Functions of Bound Sulfur}

\author{
Shinzo TANABE \\ Meiji Pharmaceutical University, 2-522-1 Noshio, Kiyose City 204-8588, Japan
}

(Received November 13, 2007)

\begin{abstract}
Inorganic sulfur compounds, such as $\mathrm{S}^{2-}, \mathrm{SO}_{3}^{2-}$ and $\mathrm{S}_{2} \mathrm{O}_{3}^{2-}$, are produced from sulfur- containing amino acids as intermediary metabolites in mammalian tissues through complex pathways and are ultimately incorporated into sulfate. Reduced sulfur is also produced via the desulfuration of cysteine by several sulfurtransferases present in mammalian tissues; these enzymes include $\gamma$-cystathionase ( $\gamma$-CST), and 3-mercaptopyruvate sulfurtransferase (3-MST). This reduced sulfur is then incorporated into pools of active reduced sulfur (sulfane sulfur; polysulfides, polythionates, thiosulfate, thiosulfonates and elemental sulfur) that are involved in the detoxication of cyanide and in the biosynthesis of iron-sulfur cluster. Sulfane sulfur is labile and is reduced to $\mathrm{H}_{2} \mathrm{~S}$ by reducing agents. The physiological function of these sulfur species is less clear. We have found that a reduced sulfur species is commonly present in mammalian sera and tissues as a high molecular weight material and as both a high and a low molecular weight material, respectvively; we designated this sulfur species as "bound sulfur." Bound sulfur can be easily liberated as sulfide by reduction with DTT. This review describes sensitive and specific assay method for determining the presence of inorganic sulfur compounds as well as bound sulfur and related sulfurtransferases in biological samples. The physiological functions of bound sulfur in rat tissues were also evaluated using these assay methods. Bound sulfur was found to be located primarily in the rat liver cytosolic fraction in the form of high molecular weight components. The capacity of bound sulfur production was enriched in the cytosol fraction and depended on $\gamma$-CST. Bound sulfur also affected redox regulation by modifying active thiol residues in some liver cytosol enzymes and effectively inhibited cytochrome P-450-dependent lipid peroxidation induced by $\mathrm{CCl}_{4}$ and $t-\mathrm{BuOOH}$.
\end{abstract}

Key words_ — inorganic sulfur compound; sulfane sulfur; bound sulfur; assay method; physiological function

\section{1. はじめに}

イオウは化学的にも生物学的にも活性な元素で, 主要な生体構成元素でもある. 主としてタンパク質 中の含硫アミノ酸であるメチオニンとシステインと して体内に取り込まれる。哺乳動物のシステインは 同化作用や異化作用で細胞に供給され，体タンパク 質やグルタチオンの合成に使われる．システインの 異化作用はFig. 1 に示すように酸化と非酸化経路 を通して起こる．酸化経路はシステインジオキシゲ

明治薬科大学分析化学教室 ( $=204-8588$ 清瀬市野塩 522-1)

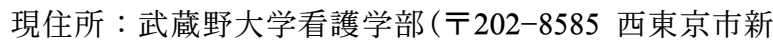
町 1-1-20)

e-mail: s_tanabe@musashino-u.ac.jp 本総説は, 平成 18 年度退職にあたり在職中の業績を中 心に記述されたものである.
ナーゼ（EC 1.13.11.20, cysteine dioxygenase）によ りシステインスルフイン酸（3-sulfino-L-alanine; CSA）を生成する（経路 1)。CSA はさらに経路 5 を経て非酵素的にピルビン酸と $\mathrm{SO}_{3}^{2-}$ に分解され， $\mathrm{SO}_{3}^{2-}$ は亜硫酸酸化酵素 (EC 1.8.3.1, sulfite oxidase) で $\mathrm{SO}_{4}^{2-}$ に酸化されるか, 経路 4 を経てヒポタウリ ン（HT）となり，酵素的又は非酵素的に酸化され てタウリンになる 2 つの応で代謝される. ${ }^{1)}$ シス テインの非酸化的経路はシスチンを介し $\gamma$-シス夕 チオナーゼ (EC 4.4.1.1, cystathionine $\gamma$-lyase; $\gamma$ CST）による反応でチオシステイン（cysteine persulfide）を経て生じる系（経路 3）と，3-メルカプ トピルビン酸（3-MP）（経路 2）を基質として 3メルカプトピルビン酸イオウ転移酵素（EC 2.8.1.2, 3-mercaptopyruvare sulfurtaransferase: 3-MST) に 


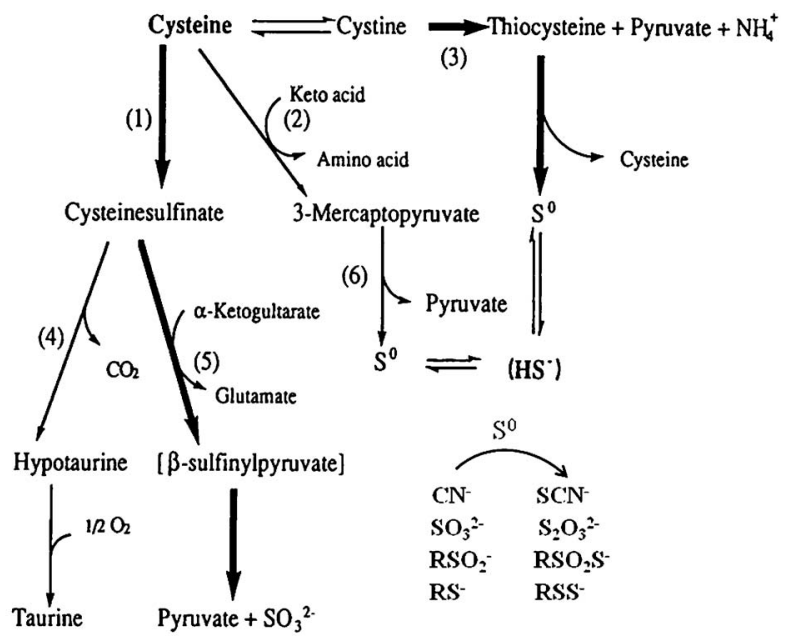

Fig. 1. Pathways of Cysteine Catabolism in Mammalian (1) Cysteine dioxygenase, (2) Cysteine aminotransferase, (3) $\gamma$ Cystathionase, (4) Cysteinesulfinate decarboxylase, (5) Aspartate amino transferase, (6) 3-Mercaptopyruvate sulfurtransferase.

より生成する（経路 6) 2つの経路が知られている. これまで, システインから $\mathrm{SO}_{4}^{2-}$ とタウリンが生成 する酸化経路が哺乳動物におけるシステイン一イオ ウの主代謝経路と考えられてきたが，Stipanuk ら は，システインの $50 \%$ 近くが無機イオウ $\left(\mathrm{S}^{0}\right)$ と ピルビン酸に分解されることを示した. ${ }^{2,3)} \mathrm{S}^{0}$ を生 成する系は非酸化的な脱硫経路と呼ばれ，生成した $\mathrm{S}^{0}$ は還元されて $\mathrm{H}_{2} \mathrm{~S}$ を遊離するか, $\mathrm{SO}_{3}^{2-}, \mathrm{CN}^{-}$, $\mathrm{RSO}_{2}^{-}$あるいは $\mathrm{RS}^{-}$のような受容体に転移され

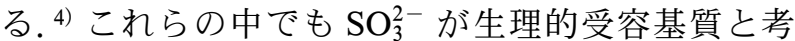
えられ, $\mathrm{S}_{2} \mathrm{O}_{3}^{2-}$ の生成を示唆しているが，イオウ原 子の存在形態や存在量を示すには至っていない.

一般に生体内でイオウ原子は安定型と不安定型の 2 つの形で存在している。最も安定な還元状態であ る -2 価（含硫アミノ酸など）で取り込まれ，4 価 （スルフィン酸類：CSA, HT）に代謝され，最も安 定な酸化状態である 6 価（スルフォン酸類： $\mathrm{SO}_{4}^{2-}$, タウリン, システイン酸）で存在している. 一方不 安定型イオウは，還元状態（0--1 価）を保ったま まなんらかの形で蓄えられ，生体内で利用され る, ${ }^{5)}$ 一方 Westley らの研究グループは, 生体内に 留まる還元状態のイオウの役割に注目し，スルファ ンプールの概念を提唱した. ${ }^{6,7)}$ Westleyによれば, 生体内には $\mathrm{CN}^{-}$と反応するのに適した電荷状態に あるイオウの生理的プールが存在し，必要に応じて $\mathrm{CN}^{-}$を $\mathrm{SCN}^{-}$として解毒排泄し，解毒に消費され

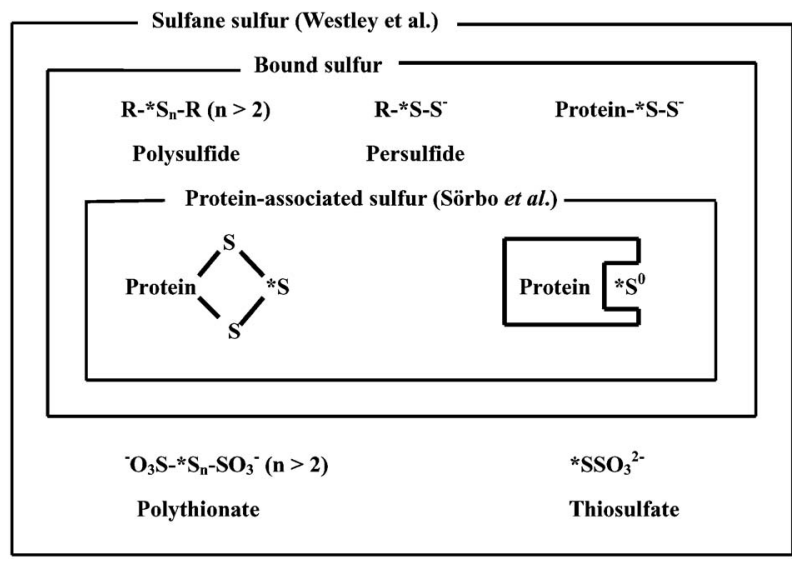

Fig. 2. Various Forms of Reduced Sulfur Defined as Bound Sulfur, Sulfane Sulfur, and Protein-associated Sulfur *Sulfane Sulfur Atom.

ないスルファンイオウの一部は，システイン等の合 成や，鉄一イオウタンパク質の合成に用いられるの ではないかと予想した。彼らは，ラットを用いた ${ }^{35} \mathrm{~S}$ 標識スルファンイオウの投与実験により, 標識 された ${ }^{35} \mathrm{SSO}_{3}^{-}$やタンパク質の存在が認められたこ とから，スルファンイオウは in vivo で相互変換さ れていることを明らかにした。 ${ }^{8)}$ Figure 2 はスルフ アンイオウ原子を含む化合物を示している. Westley が定義するスルファンイオウは，イオウ原子に の夕共有結合したイオウ原子を意味し，具体的には $\mathrm{S}_{2} \mathrm{O}_{3}^{2-}$ や過硫化物の外側のイオウ原子，ポリチオン 酸及び多硫化物の内側のイオウ原子がそれに該当す る。しかし通常は, $\mathrm{CN}^{-}$と反応して $\mathrm{SCN}^{-}$となる イオウ種あるいはイオウ転移酵素であるロダネーゼ (EC 2.8.1.1, rhodanese）の基質となり得るイオウ 種を総称してスルファンイオウと呼んでいるが，そ れらの存在量は正確に測定されておらず，哺乳動物 における生理的意義については未知な部分が多い .

本総説では，まずこれまで開発してきた生体内含 硫無機化合物を含む無機陰イオンとスルファンイオ ウに対する測定法と生体試料への応用を記述する。

筆者らはこの研究で, 哺乳動物体内にはジチオスレ イトール（DTT）還元で $\mathrm{S}^{2-}$ を遊離するイオウ種 の存在を見い出し, スルファンイオウと区別して結 合型イオウと命名した。 そこで次に，結合型イオウ とその生成に関与するイオウ転移酵素群の測定法と 生体内分布及び存在様態について述べ，その存在意 義と生理的機能について得られた成果を概説する. 
2. 含硫無機化合物を含む生体無機陰イオンの分 析法

2-1. Fe（III）を検出試薬とした分析 無機陰 イオンの一斉分析法としては, Small らが開発した イオンクロマトグラフィー（IC）が広い分野で用 いられている。しかし生体試料の分析には，固定相 に交換容量の小さいイオン交換体を用い，検出系に はイオン種のすべてに応答する電気伝導度検出器を 用いるため選択性に欠き，実用分析には不向きであ る。また, $\mathrm{UV}$ 吸収は, $\mathrm{Cl}^{-}, \mathrm{PO}_{4}^{3-}, \mathrm{SO}_{4}^{2-}$ といった 主要な陰イオンが検出できない. ${ }^{9)} \mathrm{Fe}$ (III) は主要な 無機陰イオンと有色の錯体を形成する（Table 1). そこで筆者らは，検出試薬として Fe（III）を用いる 含硫無機化合物を含む主要無機陰イオンの生体試料 にも応用できる分析法を開発した。

2-1-1. オンカラム法によるヒト尿, 血清中の遊 離 $\mathrm{SO}_{4}^{2-}$ 及び結合型 $\mathrm{SO}_{4}^{2-}, \mathrm{SCN}^{-}$の定量 生体中 $\mathrm{SO}_{4}^{2-}$ の測定は，イオウ化合物や含硫アミノ酸の代 謝，腎機能との関係などを知る上で重要である。口 ジゾン酸による比色法が，尿中の微量定量に応用さ れているが， $\mathrm{Cl}^{-}$など妨害による発色の不安定さか ら血清での応用は困難であった。 ${ }^{10)}$ 筆者らは $\mathrm{Fe}_{2}$ $\left(\mathrm{SO}_{4}\right)_{3}$ 錯体の UV 吸収 $(340 \mathrm{~nm}$, Table 1) を検出 する HPLCによる硫酸分析計を用いて，簡便でか つ感度のよい血清，尿中の遊離 $\mathrm{SO}_{4}^{2-}$ と結合型 $\mathrm{SO}_{4}^{2-}$ の測定を行った. ${ }^{11)}$ 力ラムは強塩基性陰イ才 ン交換樹脂，溶離液は $5 \mathrm{mMFe}\left(\mathrm{NO}_{3}\right)_{3}$ を含む 0.1 $\mathrm{mM} \mathrm{HNO}_{3}$ 水溶液を用い, カラム上で生成した有色
の $\mathrm{Fe}_{2}\left(\mathrm{SO}_{4}\right)_{3}$ 錯体を分離検出する，遊離 $\mathrm{SO}_{4}^{2-}$ 測定 の場合，尿試料は 5 倍希釈尿 $10 \mu \mathrm{l}$ を，血清試料は， $20 \%$ トリクロロ酢酸（TCA）で除タンパクした上 澄液 $100 \mu \mathrm{l}$ を直接注入する。結合型 $\mathrm{SO}_{4}^{2-}$ 測定の場 合は，各試料とも $3 \mathrm{M}$ 塩酸で加熱加水分解後，過剩 の $\mathrm{Cl}^{-}$を $\mathrm{Ag}_{2} \mathrm{O}$ で処理した上澄液を用いる。健常 人血清試料中 $(n=8)$ 遊離 $\mathrm{SO}_{4}^{2-}$ と結合型 $\mathrm{SO}_{4}^{2-}$ は それぞれ $3.43 \mathrm{mg} / \mathrm{dl}[(3.04-3.76) \mathrm{mg} / \mathrm{dl}$, c.v. $=8.5$ $\%$ ] $1.50 \mathrm{mg} / \mathrm{dl}[(1.14-1.99) \mathrm{mg} / \mathrm{dl}, \mathrm{c.v} .=22 \%]$ で, $\mathrm{SO}_{4}^{2-}$ 濃度には個人差が少なかった。一方，尿試料 中 $(n=7)$ の遊離 $\mathrm{SO}_{4}^{2-}$ と結合型 $\mathrm{SO}_{4}^{2-}$ は，それぞ れ $1.41 \mathrm{mg} / \mathrm{ml}[0.28-2.85) \mathrm{mg} / \mathrm{ml}$, c.v. $=57.4 \%]$, $0.26 \mathrm{mg} / \mathrm{ml}[(0.07-0.49) \mathrm{mg} / \mathrm{ml}, \mathrm{c.v} .=57.5 \%]$ と測 定値に個人差がみられた。本法はロジゾン酸法に比 べ，血清試料で約 16 倍，尿試料で 5 倍高感度で, $\mathrm{Cl}^{-}$など妨害物質の影響を受けず，特に血清試料に 対しては操作も簡便で十分臨床分析に適応できる方 法である.

$\mathrm{SCN}^{-}$は， $\mathrm{SO}_{4}^{2-}$ と同様 $\mathrm{Fe}(\mathrm{III})$ と有色の錯体を形 成する (Table 1).この検出系がオートアナライザー に組み込まれ，喫煙のマーカーとして臨床検査に用 いられているが，特異性に問題がある. ${ }^{12)} \mathrm{König} \mathrm{反}$ 応を用いた比色法や, ${ }^{13)}$ 電子捕獲検出器を用いるガ スクロマトグラフィー $(\mathrm{GC})^{14)}$ は，感度，特異性の 点で $\mathrm{Fe}$ (III) 錯体形成法より優れているが，定量操 作が煩雑でルーチン分析には向いていない。筆者ら は，オートアナライザーの欠点を改良すべく， Fe $(\mathrm{SCN})_{3}$ 錯体をオンカラム上で生成させ，HPLCで

Table 1. Complex Formation of Inorganic Anions with $\mathrm{Fe}(\mathrm{III})$

\begin{tabular}{llclcr}
\hline \hline \multicolumn{1}{c}{ Anion } & $\lambda_{\max }(\mathrm{nm})$ & Detection limit $(\mathrm{nmol})$ & Anion & $\lambda_{\text {max }}(\mathrm{nm})$ & Detection limit (nmol) \\
\hline $\mathrm{CrO}_{4}^{2-}$ & 305,344 & 0.4 & $\mathrm{SO}_{3}^{2-}$ & 308 & 12.7 \\
$\mathrm{SCN}^{-}$ & 310 & 1.3 & $\mathrm{PO}_{3}^{3-}$ & - & 24.8 \\
$\mathrm{Fe}(\mathrm{CN})_{6}^{4-}$ & 305 & 1.6 & $\mathrm{H}_{2} \mathrm{PO}_{2}^{-}$ & - & 28.8 \\
$\mathrm{Fe}(\mathrm{CN})_{6}^{3-}$ & 305 & 1.9 & $\mathrm{IO}_{3}^{-}$ & - & 73.7 \\
$\mathrm{SO}_{4}^{2-}$ & 306 & 2.8 & $\mathrm{CO}_{3}^{2-}$ & - & 141.3 \\
$\mathrm{Cl}^{-}$ & 335 & 4.8 & $\mathrm{Br}^{-}$ & - & 144.3 \\
$\mathrm{P}_{2} \mathrm{O}_{7}^{4-}$ & 310 & 5.2 & $\mathrm{~B}_{4} \mathrm{O}_{7}^{2-}$ & - & 206.4 \\
$\mathrm{I}^{-}$ & 306,350 & 5.6 & $\mathrm{BrO}_{3}^{-}$ & - & 931.7 \\
$\mathrm{P}_{3} \mathrm{O}_{10}^{5-}$ & 310 & 6.4 & $\mathrm{CN}^{-}$ & - & 392.2 \\
$\mathrm{~S}^{2-}$ & - & 7.1 & $\mathrm{SiO}_{3}^{2-}$ & - & 285.7 \\
$\mathrm{~S}_{2} \mathrm{O}_{3}^{2-}$ & 308 & 8.1 & $\mathrm{NO}_{3}^{-}$ & - & - \\
$\mathrm{NO}_{2}^{-}$ & 372,360 & 10.8 & $\mathrm{~F}^{-}$ & - & - \\
$\mathrm{PO}_{4}^{3-}$ & 310 & 11.8 & $\mathrm{ClO}_{3}^{-}$ & - & - \\
\hline
\end{tabular}

Reactions were carried out in $0.8 \mathrm{M} \mathrm{HClO}_{4}$ containing $0.05 \mathrm{M} \mathrm{Fe}\left(\mathrm{ClO}_{4}\right)_{3}$. UV spectra were measured within 5 min using a reagent blank as a reference. 
分離検出する硫酸分析計と同じ方式で尿及び血清試 料中の $\mathrm{SCN}^{-}$の微量定量法を確立した. ${ }^{15)}$ 分離カラ 厶に強塩基性陰イオン交換樹脂，溶離液に $0.02 \mathrm{mM}$ $\mathrm{Fe}\left(\mathrm{ClO}_{4}\right)_{3}$ を含む $0.06 \mathrm{M} \mathrm{HClO}_{4}$ 溶液, 検出波長 $460 \mathrm{~nm}$ を用いることで無機陰イオン及び有機酸の 妨害なく， 0.25-10 $\mathrm{nmol}$ の $\mathrm{SCN}^{-}$を測定すること ができた。本法の特長は，血清試料中のアルブミン 結合型と非結合型の分別定量を chaotropic 効果の 大きい $\mathrm{HClO}_{4}$ を除タンパク剂と溶離液に用いてい ることで，除タンパク液より総量を，血清の限外ろ 過液より非結合型 $\mathrm{SCN}^{-}$の測定が可能なことであ る。健常人尿 $(n=6)$ は 39.6-171.4 $\mu \mathrm{mol} / 1$ と測定 值に幅があり，血清 $(n=6)$ についても総 $\mathrm{SCN}^{-}$ 量は 0.6-8.3 $\mu \mathrm{mol} / 1$, 非結合型は $0.4 \sim 5.0 \mu \mathrm{mol} / \mathrm{dl}$ と尿試料同様測定值に幅があつたが，結合型 $\mathrm{SCN}^{-}$ 量/総 $\mathrm{SCN}^{-}$量は $39.1 \pm 7.85 \%$ と変動範囲が狭い ことが分かった。また，高值（尿：171.4 $\mu \mathrm{mol} / 1$, 血清 : $8.3 \mu \mathrm{mol} / \mathrm{l})$ を示したのはすべて喫煙者であ つた.

2-1-2. ポストカラム HPLC による無機陰イオン の一斉分析 $\mathrm{Fe}(\mathrm{III})$ で有色錯体を生成する無機 陰イオン（Table 1) のポストカラム HPLC による 一斉分析法を試みた. ${ }^{16)}$ 検出波長は試薬ブランクの 吸収が $300 \mathrm{~nm}$ 近辺に観察されるので $340 \mathrm{~nm}$ とし た.この波長で $\mathrm{CrO}_{4}^{2-}$ から $\mathrm{SO}_{3}^{2-}$ まで 14 種の無機 陰イオンが最大吸光度の 60-70\%で検出できる。分 析カラムはシリカ系のイオン交換カラム TSK-gel IEX-520 QAE， Fe(III) 試薬は配位性が少なく試薬 ブランクの吸光度も小さい $0.05 \mathrm{M} \mathrm{Fe}\left(\mathrm{ClO}_{4}\right)_{3}$ を含む $0.8 \mathrm{M} \mathrm{HClO}_{4}$ 溶液を用いた。 $\mathrm{PO}_{4}^{3-}, \mathrm{Cl}^{-}, \mathrm{NO}_{2}^{-}$, $\mathrm{SO}_{4}^{2-}, \mathrm{S}_{2} \mathrm{O}_{3}^{2-}, \mathrm{I}^{-}, \mathrm{SCN}^{-}$各陰イオンは $0.1 \mathrm{M} \mathrm{NaNO}_{3}$ 水溶液で 30 分以内に完全に分離された $[$ Fig. 3 (a) ]. $\mathrm{Fe}(\mathrm{CN}){ }_{6}^{4-}, \mathrm{Fe}(\mathrm{CN}){ }_{6}^{3-}$ はこの分離系では樹脂 に吸着し溶離できなかったが， $0.05 \mathrm{M} \mathrm{NaNO}_{3}$ を含 む $0.05 \mathrm{M}$ 酷酸緩衝液（pH 5.48）を用いることで 20 分以内に残りの 7 つ無機陰イオンとともに完 全に分離できた $[\mathrm{Fig} .3(\mathrm{~b})]$ 。本法は, $\mathrm{Cl}^{-}, \mathrm{SO}_{4}^{2-}$, $\mathrm{SCN}^{-}$が 2-500 nmol, $\mathrm{PO}_{4}^{3-}, \mathrm{NO}_{3}^{-}, \mathrm{S}_{2} \mathrm{O}_{3}^{2-}$ が 8-5000 $\mathrm{nmol}$ の範囲で精度よく測定できる。排水より $\mathrm{Cl}^{-}$ と $\mathrm{SO}_{4}^{2-}$ が $\left[\right.$ Fig. 3 (c) ] , 尿中より $\mathrm{PO}_{4}^{3-}, \mathrm{Cl}^{-}$, $\mathrm{SO}_{4}^{2-}$ と微量の $\mathrm{SCN}^{-}$が [Fig. 3(d)] $10 \mu \mathrm{l}$ の試料 で測定できた。 また，ICに比べて高濃度な塩を溶 離液に用いているので，簡単な前処理で生体試料に

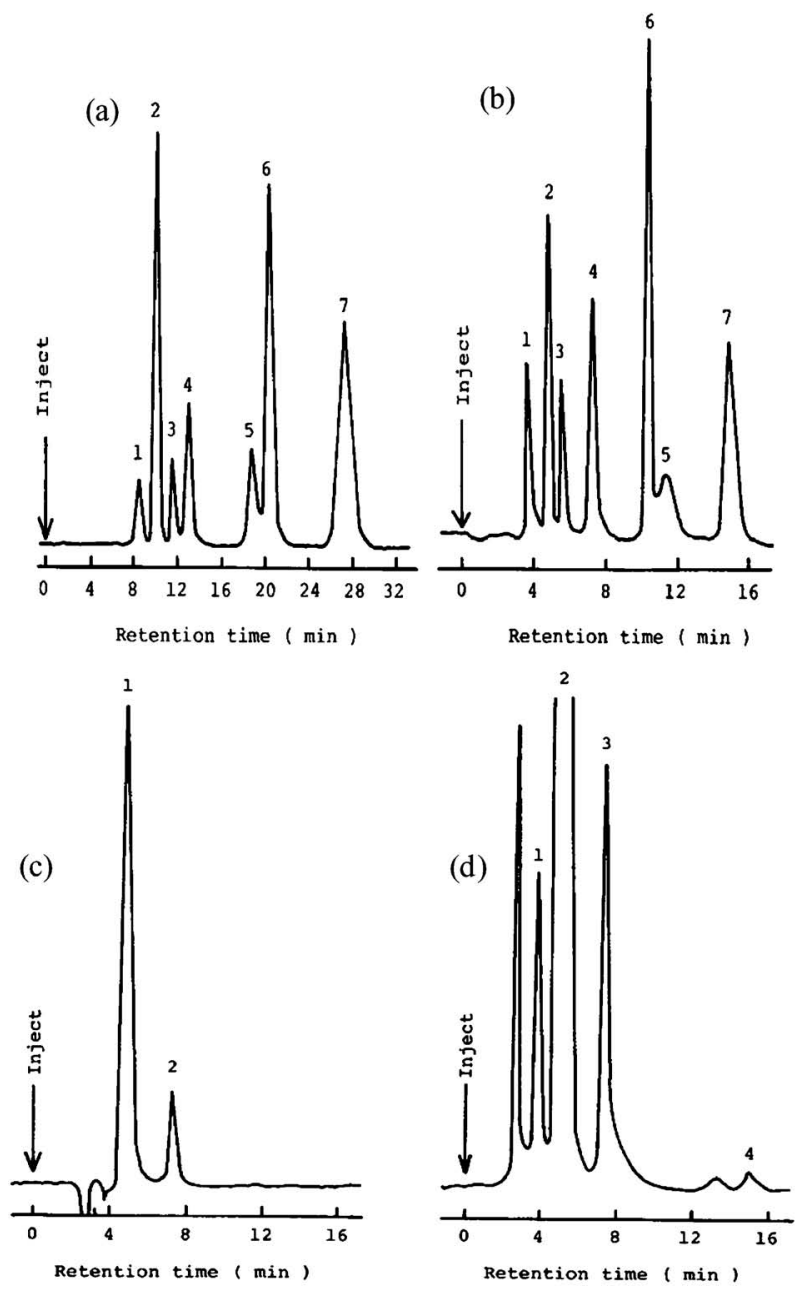

Fig. 3. Chromatograms of a Standard Mixture of Inorganic Anions (a, b), Waste Water (c) and Human Urine (d)

(a) Eluent, $0.1 \mathrm{M} \mathrm{NaNO}_{3}$; flow-rate: $0.32 \mathrm{ml} / \mathrm{min}$. Peaks: $1=\mathrm{PO}_{4}^{3-} ; 2=$ $\mathrm{Cl}^{-} ; 3=\mathrm{NO}_{2}^{-}, 4=\mathrm{SO}_{4}^{2-}, 5=\mathrm{S}_{2} \mathrm{O}_{3}^{2-}, 6=\mathrm{I}^{-}, 7=\mathrm{SCN}^{-}$. (b) Eluent, 0.05 $\mathrm{M}$ acetate buffer ( $\mathrm{pH}$ 5.48) containing $0.05 \mathrm{M} \mathrm{NaNO}_{3}$, flow-rate: $0.8 \mathrm{ml} / \mathrm{min}$. Peaks: $1=\mathrm{PO}_{4}^{3-}, 2=\mathrm{Cl}^{-}, 3=\mathrm{NO}_{2}^{-}, 4=\mathrm{SO}_{4}^{2-}, 5=\mathrm{S}_{2} \mathrm{O}_{3}^{2-}, 6=\mathrm{I}^{-}, 7=\mathrm{SCN}^{-}$. (c) Sample size, $10 \mu \mathrm{l} / / \mathrm{ml}$. Peaks: $1=\mathrm{C1}^{-}(200 \mathrm{nmol}), 2=\mathrm{SO}_{4}^{2-}(15 \mathrm{nmol})$. (d) Sample size, $10 \mu \mathrm{l} / / \mathrm{ml}$. Peaks: $1=\mathrm{PO}_{4}^{3-}(257 \mathrm{nmol}), 2=\mathrm{Cl}^{-}(1800$ $\mathrm{nmol}) .3=\mathrm{SO}_{4}^{2-}(100 \mathrm{nmol}), 4=\mathrm{SCN}^{-}(1.4 \mathrm{nmol})$.

応用できる.

\section{2-2. 含硫無機化合物の分析}

2-2-1. $\mathrm{S}^{2-}, \mathrm{SCN}^{-}, \mathrm{S}_{2} \mathrm{O}_{3}^{2-}, \mathrm{SO}_{3}^{2-}, \mathrm{NO}_{2}^{-}$の同時分 析生体内ではシステインの異化作用で $\mathrm{S}^{2-}$, $\mathrm{SO}_{3}^{2-}, \mathrm{S}_{2} \mathrm{O}_{3}^{2-}, \mathrm{SCN}^{-}, \mathrm{RSO}_{2}^{-}$など還元性を示す含硫 無機化合物が存在する（Fig. 1)。これらはすべ電 気的に活性であり, 電気化学検出器 (ECD) が高 感度分析に威力を発揮する．筆者らは，作用電極に 炭素 (glassy carbon) 電極を用いた ECD 検出 (0.9 V vs. $\mathrm{Ag} / \mathrm{AgCl})$ による $\mathrm{SCN}^{-}, \mathrm{S}_{2} \mathrm{O}_{3}^{2-}, \mathrm{SO}_{3}^{2-}$ と $\mathrm{NO}_{2}^{-}$の HPLCによる一斉分析の基礎的検討を，分 析カラムに TSK-GEL IEX-520 QAE，溶離液に 
$0.05 \mathrm{M} \mathrm{NaNO}_{3}$ を含む $0.05 \mathrm{M}$ リン酸緩衝液 $(\mathrm{pH} 7.5)$ を用いて行い， 20 分以内に各イオンを 0.015-15, $0.05-15,2.5-80,0.012-1 \mu \mathrm{g} / \mathrm{ml}$ の濃度範囲で測定で

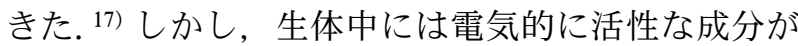
多くこの条件では生体試料に応用することは難しい.

1983 年 Sörbo らは同時分析ではないが，外傷患 者尿中の $\mathrm{S}_{2} \mathrm{O}_{3}^{2-}$ を作用電極に水銀電極を用いた ECD-逆相 HPLC で測定している. ${ }^{18)}$ 彼らの方法 は，筆者らの炭素電極を用いる方法より，感度，選 択性で優れており， $0.3 \mu \mathrm{mol} / 1$ まで $\mathrm{S}_{2} \mathrm{O}_{3}^{2-}$ が検出で きるが，検出器が自家製のため汎用的ではなかつ た。筆者らは，ECD の欠点である選択性を克服す

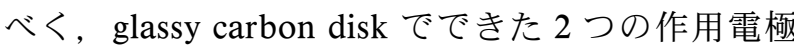
$\left(\mathrm{W}_{1}, \mathrm{~W}_{2}\right)$ を溶離液 $\left(0.18 \mathrm{M} \mathrm{NaNO}_{3}\right)$ の流れる両面 に設置した dual electrochemical detector（DECD : $\mathrm{W}_{1}=0.7 \mathrm{~V}, \mathrm{~W}_{2}=0.9 \mathrm{~V}$ ）を用いた強塩基性陰イオン 交換樹脂による HPLC で，ヒト尿及び血漿中の $\mathrm{S}_{2} \mathrm{O}_{3}^{2-}$ をSörbo らの方法と同感度で測定できた（正 常尿 : $n=5 ; 31.2 \pm 15.9 \mu \mathrm{mol} / \mathrm{d}$ ，血漿 : $n=5$; $2.68 \pm 0.23 \mathrm{nmol} / \mathrm{ml})$. ${ }^{19)}$

$\mathrm{Ce}$ (IV) は $\mathrm{Ce}$ (III) に還元されると蛍光を呈する. この性質を利用して $\mathrm{NO}_{3}^{-}, \mathrm{NO}_{2}^{-}, \mathrm{S}_{2} \mathrm{O}_{3}^{2-}, \mathrm{I}^{-}$が ppb レベルで同時分析されている. ${ }^{20)}$ 筆者らは，この試 薬に着目し, $\mathrm{Ce}(\mathrm{IV})$ を蛍光検出試薬に用いたポス トカラム HPLCによる $\mathrm{S}^{2-}, \mathrm{SCN}^{-}, \mathrm{S}_{2} \mathrm{O}_{3}^{2-}$ 及び $\mathrm{NO}_{2}^{-}$の一斉分析法を開発し, ヒト唾液中の $\mathrm{SCN}^{-}$ と $\mathrm{NO}_{2}^{-}$及び血清中の遊離型 $\mathrm{SCN}^{-}$の測定に応用し た. ${ }^{21)}$ 分離カラムは ECD-HPLC の場合と同じカラ 厶を用い，溶離液に $0.05 \mathrm{M} \mathrm{NaNO}_{3}$ 水溶液, $\mathrm{Ce}$ (IV) の自己還元を防ぐためにビスマス酸ナトリウムを加 え，反応コイルを $80^{\circ} \mathrm{C}$ で 15 秒に保つことで反応を 終結させる．検出は励起波長 $260 \mathrm{~nm}$ における蛍光 波長 $360 \mathrm{~nm}$ でモニターする，尿及び血清試料は Amicon MPS-1 micropartition system で限外ろ過 後, そのろ液 $20 \mu \mathrm{l}$ をカラムに注入する. 検出限界 は $\mathrm{NO}_{2}^{-}, \mathrm{SCN}^{-}$で $0.1 \mathrm{nmol}, \mathrm{S}_{2} \mathrm{O}_{3}^{2-}$ で $0.3 \mathrm{nmol}, \mathrm{S}^{2-}$ で $0.8 \mathrm{nmol}$ ，と 4 イオンとも少なくとも $10 \mathrm{nmol}$ まで定量できたが，検出限界は ECD-HPLC の約 20 倍であった。しかし上述した前処理法で生体成 分の妨害を受けず，唾液中の $\mathrm{SCN}^{-}$と $\mathrm{NO}_{2}^{-}$と血清 中の $\mathrm{SCN}^{-}$が測定できた. $\mathrm{SCN}^{-}$濃度は喫煙者（唾 液 : 0.89 と $1.30 \mathrm{mM}$, 血清 : $n=4,50.2 \pm 11.4 \mu \mathrm{M}$ )

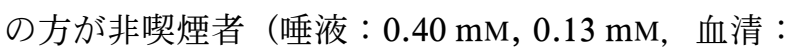

$n=6,12.6 \pm 3.3 \mu \mathrm{M})$ より明らかに高值を示した. 一方, $\mathrm{NO}_{2}^{-}$は喫煙者（唾液：0.03 と $0.19 \mathrm{mM}$ ） と 非喫煙者（唾液：0.13 mM）では有意な差はみられ なかった。 なお血清中の $\mathrm{NO}_{2}^{-}$及び $\mathrm{S}_{2} \mathrm{O}_{3}^{2-}$ は，本法 では定量限界以下であった。この結果は，喫煙のモ リタリングに血液でなく唾液試料で十分臨床的に利 用可能であることを示唆している.

Lundquist らは König 反応を用いて $\mathrm{SCN}^{-}$を特 異的に測定しているが, ${ }^{13)} \mathrm{Fe}$ (III) 試薬を用いる筆 者らの方法15)より定量操作が煩雑で測定感度は同じ であった．そこで筆者らは，これらの点を考慮し， 生体内 $\mathrm{CN}^{-}$及び $\mathrm{SCN}^{-}$の König 反応を用いたポス トカラム HPLCによる同時定量法を確立した. ${ }^{22)}$ 分離カラムにポリスチレン系の強塩基性陰イオン交 換樹脂，移動相に $0.2 \mathrm{M} \mathrm{NaClO}_{4}$ を含む $0.1 \mathrm{M}$ 酢酸 緩衝液（pH 5.0）を用い，呈色試薬としてクロラミ ン $\mathrm{T}$ 水溶液とバルビツール酸一ピリジンの塩酸酸 性溶液を流し，580 nm でモニターする。両イオン の定量限界は $20 \mathrm{pmol}$ で Funazo らのガスクロマト グラフィー23)に匹敵した。 また， $\mathrm{SCN}^{-}$については $\mathrm{Fe}$ (III) 錯体 -HPLC より約 100 倍高感度であった. 喫煙者と非喫煙者尿について測定した結果 $(n=6)$, $\mathrm{SCN}^{-}$はそれぞれ $171 \mu \mathrm{M}, 17.4 \mu \mathrm{M}, \mathrm{CN}^{-}$は喫煙者 で定量限界以下，非喫煙者は検出されなかった。ま た，本法で得られた呈色物質は強い蛍光を示した

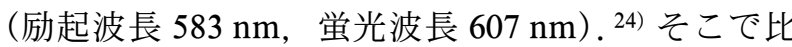
色法と同じポストカラム HPLC 条件で, ${ }^{22)}$ 蛍光モ ニターで測定したところ，比色による検出に比べ約 10 倍高感度で $\mathrm{CN}^{-}, \mathrm{SCN}^{-}$（定量限界：2 pmol）の 同時定量が可能となり，ヒ卜血漿及び赤血球中の $\mathrm{CN}^{-}, \mathrm{SCN}^{-}$の測定に応用した. ${ }^{25)} \mathrm{CN}^{-}$の測定は, Conway Cell 拡散法で前処理し, $\mathrm{NaOH}$ 吸収液に 吸収された $\mathrm{CN}^{-}$を HPLC で分析する. $\mathrm{SCN}^{-}$が共 存する血球試料は，アーチファクトな $\mathrm{CN}^{-}$への分 解を防ぐためにアスコルビン酸を加える．血球中の $\mathrm{SCN}^{-}$は， $\mathrm{NaClO}_{4}$ を含むりン酸緩衝液（pH 8.0） を加え，限外ろ過し，万液を試料とする。血漿中の $\mathrm{SCN}^{-}$の測定は, $\mathrm{HClO}_{4}$ 除タンパクした上澄液を 用いる。 $\mathrm{CN}^{-}$は血球にのみ存在し，そのほとんど は “stable cyanaide” $(n=7,0.13-0.42 \mu \mathrm{M})$ であっ た。また，血漿 $(n=7,12.0-90.0 \mu \mathrm{M})$ と同等の濃 度で血球中にも $\mathrm{SCN}^{-}(n=7,8.0-84.7 \mu \mathrm{M})$ が観察 された。 
2-2-2. Monobromobimane（MBB）を用いたヒト 血清中結合型 $\mathbf{S}^{2-}$ と $\mathbf{S O}_{3}^{2-}, \mathbf{S}_{2} \mathbf{O}_{3}^{2-}$ の分析 Shea と Howell は, ${ }^{26)}$ チオール類の蛍光ラベル化剤 MBB を用いるプレカラム HPLC で内因性の $\mathrm{S}_{2} \mathrm{O}_{3}^{2-}$ を $0.16 \mathrm{nmol} / 50 \mu \mathrm{l}$ injection まで測定している。彼ら の方法の欠点は, 試料由来の不純物や蛍光性の $\mathrm{MBB}$ 加水分解物由来のピーク類と完全に分離でき ないことであった，筆者らは，含硫無機化合物の蛍 光ラベル化剂としての MBB の反応性を再検討し, $\mathrm{S}_{2} \mathrm{O}_{3}^{2-}$ 以外に $\mathrm{S}^{2-}, \mathrm{SO}_{3}^{2-}$ が強く発蛍光することを見 い出した。 そこで $\mathrm{MBB}$ を用いる $\mathrm{S}^{2-}, \mathrm{SO}_{3}^{2-}, \mathrm{S}_{2} \mathrm{O}_{3}^{2-}$ のプレカラム HPLC による同時測定法の開発を試 みた. ${ }^{27)}$ 蛍光誘導体化は, MBB のアセトニトリル 溶液中, 暗所で 60 分間, 室温で行う。MBB 誘導 体は，弱塩基性陰イオン交換カラムに接続された逆 相 ODS カラムによる coupled columun で, $25 \mathrm{~mm}$ $\mathrm{NaClO}_{4}$ を含む酢酸溶液（ $\left.\mathrm{pH} 3\right)$-アセトニトリル $(13: 3 \mathrm{v} / \mathrm{v})$ の移動相による isocratic 溶出で分離す る. $\mathrm{S}^{2-}, \mathrm{SO}_{3}^{2-}, \mathrm{S}_{2} \mathrm{O}_{3}^{2-}$ の $\mathrm{MBB}$ 誘導体は完全に分離 され (Fig. 4(A)), 検出は蛍光モニター (Ex. 396 nm，Em. $476 \mathrm{~nm}$ ) で行った。健常人ヒト血清試料 を Amicon MPS-1 micropartition system で限外ろ過 し，ろ液を $\mathrm{MBB}$ 誘導体化後本法を用いて測定した ところ, $\mathrm{S}_{2} \mathrm{O}_{3}^{2-}$ の $\mathrm{MBB}$ 誘導体ピークのみが他の妨 害ピークなく完全に分離された $[\mathrm{Fig} .4(\mathrm{~B})]$ ．回収 率は 100.8-96.0\%で，正常血清中の $\mathrm{S}_{2} \mathrm{O}_{3}^{2-} レ$ レ゙ は $0.61 \pm 0.07 \mu \mathrm{M} \quad(n=5)$ で, DECD-HPLC で得ら れた血漿中の測定値 ${ }^{19)}$ より低值であったが，直接 測定できる本法の方が正確で優れていると思われる。

血清中の $\mathrm{SO}_{3}^{2-}$ は内因性のジスルフィド化合物と 反応し主として結合型の S-sulfonate 類として存在 しているが, ${ }^{28,29)} \mathrm{S}^{2-}$ も内因性の化合物と結合型イ オウとして存在し検出されなかった，結合型イオウ

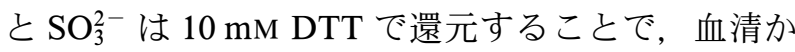
ら $\mathrm{S}^{2-}, \mathrm{SO}_{3}^{2-}$ として遊離させ, 限外ろ過後 $\mathrm{MBB}$ 誘 導体化を行い直接 HPLC を行うと, Fig. $4(C)$ に示 すように血清中のジスルフィド化合物由来のチオー ル-MBB 誘導体ピークが両イオンのピークと重な り検出不能であった。 そこで，前処理装置として自 家製の連続流れガス透析装置を作成し前処理を行つ た。試料溶液 $500 \mu \mathrm{l}$ を $20 \%$ リン酸溶液に注入し， 遊離した $\mathrm{H}_{2} \mathrm{~S}$ を PFT 膜を通して拡散させ， $10 \mathrm{mM}$ グリセリンと $5 \mathrm{mM}$ EDTA を含む $0.1 \mathrm{M} \mathrm{NaOH}$ 吸

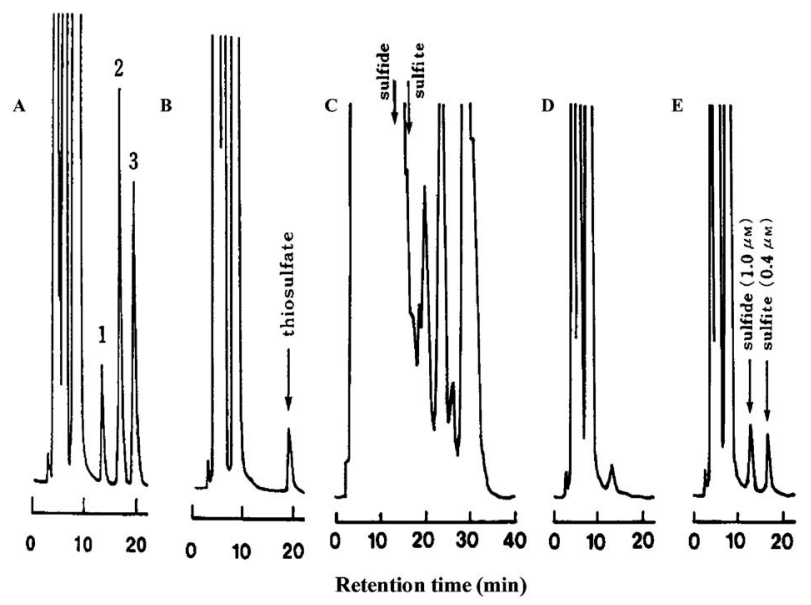

Fig. 4. Chromatograms of Standards (A) and Human Serum Treated with Ultrafiltration (B), and with (D and E) and without (C) Gas Dialysis Treatment

(A) 1, sulfide $(0.5 \mu \mathrm{M}), 2$ : sulfite $(0.5 \mu \mathrm{M}), 3$ : thiosulfate $(0.5 \mu \mathrm{M})$. (C: human serum spiked with sulfide and sulfite at $1 \mu \mathrm{m}$ each, (D): DTT, (E) human serum.

収液に吸収させる。 $50 \mu \mathrm{l}$ の吸収液を集め，MBB 誘 導体化した後 HPLC 分離を行う. Figure $4(E)$ に示 すように，妨害ピークの影響なく両イオンが完全に 分離された。定量範囲は， $\mathrm{S}^{2-}$ で 0.5-20 $\mu \mathrm{M}, \mathrm{SO}_{3}^{2-}$ で $0.2-20 \mu \mathrm{M}$, 回収率は $1.0 \mu \mathrm{M}$ 添加で, $\mathrm{S}^{2-}$ は $100.2 \%, \mathrm{SO}_{3}^{2-}$ は $101.1 \%$ と良好であった。血清中 DTT 還元で遊離する結合型 $\mathrm{S}^{2-}$ は $1.30 \pm 0.60 \mu \mathrm{M}$, 結合型 $\mathrm{SO}_{3}^{2-}$ は $0.47 \pm 0.25 \mu \mathrm{M}$ と微量ながら内因性 の結合型両イオンの存在が明らかとなった.

\section{2-3. スルフィン酸の分析システインの酸化} 経路で生成する CSA と HT はスルフィン酸誘導体 $\left(\mathrm{R}-\mathrm{SO}_{2}^{-}\right)$で，スルホン酸誘導体（R-SO $\mathrm{SO}_{3}^{-} ）$ である タウリン生合成の重要な中間体である（Fig. 1).

システイン代謝と両物質の生理作用を知る上で，哺 乳動物組織中の CSA, HT 量を測定することは重要 である．生体における両物質はごく微量で, $\mathrm{nmol}$ レベルの測定法を必要とする，筆者らは，CSA と HT が酸化され易いことに着目し，ECD-HPLCに よる高感度な生体中の同時定量法を試みた. ${ }^{30)} \mathrm{CSA}$ と HT は $\mathrm{pH} 2-8$ において $\mathrm{Ag} / \mathrm{AgCl}$ に対して 0.86 $\mathrm{V}$ で不可逆的酸化を受ける. 印加電位をさらに上げ ると両物質のレスポンスも増加するが, $1.0 \mathrm{~V}$ 以上 でベースラインが不安定になるので, 印加電位は $0.95 \mathrm{~V}$ とした。CSA は HT よりも酸性物質で，陽 イオン交換樹脂では保持されない，そこで両者の分 離は，移動相として $50 \mathrm{~mm}$ クエン酸リチウム緩衝 
液（pH 2.50）を用い，陽イオン交換樹脂カラムで HT を，陰イオン交換樹脂カラムで CSA を分離す る 2 本カラムシステムを用いるカラムスイチングシ ステムを導入した。陽イオンカラムに吸着している 生体由来の不純物は次のカラムで分離している間に 洗い流す。本法は 40 分以内で両物質を分離するこ とができ， $0.5 \mathrm{pmol} / 25 \mu \mathrm{l}$ まで検出された。ラット 各組織のホモジネートを用いた回収率は 91-105\% と良好で，ラット脳，肝臓，腎臓中 $(n=5)$ の内 因性 CSA と HT は，それぞれ $2.7 \pm 2.5 \mathrm{nM} / \mathrm{g}$ と $34.9 \pm 11.2 \mathrm{nM} / \mathrm{g}, 0.15 \pm 0.30 \mathrm{nM} / \mathrm{g}$ と $32.5 \pm 15.7$ $\mathrm{nM} / \mathrm{g}, 6.1 \pm 3.8 \mathrm{nM} / \mathrm{g}$ と $153.6 \pm 82.9 \mathrm{nM} / \mathrm{g}$ であった. Ida と Kuriyama ${ }^{31)}$ 及び Hirschberger ら ${ }^{32)}$ は， $O$ - フ タルアルデヒド（OPA）蛍光検出 HPLC でラット 脳, 肝藏, 腎臓組織中の CSA 量を測定している が，前者は脳組織で筆者らより約 10 倍高い值を, 後者は検出されなかったと報告している，筆者らは， OPA 蛍光検出 HPLC で CSA と HT を測定したと ころ，ECD-HPLCで得られた CSA 量は，OPA 蛍 光検出 HPLC では検出限界以下であり, 脳組織中 の HT も検出されなかった。しかし，肝臓及び腎 臓組織中の HT 量は，それぞれ $39.7 \pm 15.4 \mathrm{nM} / \mathrm{g}$, $192.2 \pm 22.7 \mathrm{nM} / \mathrm{g}$ と ECD-HPLC で得られた測定值 と同じオーダで測定された。

\section{2-4. 酸不安定イオウ, 結合型イオウの分析}

2-4-1. 酸不安定イオウの分析 Westley らが 定義する「スルファンイオウ」，筆者らが定義する 「結合型イオウ」, Sörbo らが定義する「タンパク質 結合型イオウ」の関係は Fig. 2 に示してある。こ れらイオウ種のイオウは最終的に $\mathrm{S}^{2-}$ に変換して 測定することになり，これらイオウの生理的意義を 研究する上で $\mathrm{S}^{2-}$ の高感度測定法と各イオウ種を 分別する前処理法の検討が必要となる. Savage ら は, ${ }^{33,34)}$ ウシの脳組織と胃液中の酸不安定イオウを $N, N$-dimethyl- $p$-phenylenediamine $\subset \mathrm{FeCl}_{3}$ 存在下 メチレンブルー色素（検出波長：670 nm）に変換 し，プレカラム誘導体化逆相 HPLC で測定してい る。本法は，100 pg-200 ng の $\mathrm{S}^{2-}$ が定量でき，正 常ウシ脳組織中酸不安定イオウが $166 \pm 31.0 \mathrm{nmol} /$ g wet weight, ${ }^{33)}$ マウス脳, 肝臓, 腎臓組織中でそ れぞれ $68.9 \pm 11.3(n=25) ， 144.5 \pm 12.4(n=9)$ ， 200.1 $\pm 46.4(n=9) \mathrm{nmol} / \mathrm{g}$ wet weight $^{34)}$ と測定さ れている，Goodwin らは，前処理にガス透析を用
いた IC-ECD による微量 $\mathrm{S}^{2-}$ の分析法を開発し, 脳組織中の酸不安定イオウの測定に応用してい る. ${ }^{35)}$ ヒト，ラットの脳組織をアルカリ性でホモジ ネートし，試料中の酸不安定イオウを酢酸亜鉛で不 溶性の ZnS とし，Technicon gas dialysis を用いる 連続流れガス透析装置を用い, $\mathrm{HCl}$ で遊離した $\mathrm{H}_{2} \mathrm{~S}$ ガスを $\mathrm{NaOH}$ 溶液中で回収したあと，銀作用電極一 ECD 検出 IC で分析している。検出限界は $0.02 \mu \mathrm{g} /$ $\mathrm{g}$ 脳組織で，ヒ卜剖検脳幹試料 $(n=45)$ では $0.69-$ $0.59 \mu \mathrm{g} / \mathrm{g}$ 脳組織，ラット脳組織中では 1.57-2.30 $\mu \mathrm{g} / \mathrm{g}$ 脳組織の酸不安定イオウー濃度を測定してい る。しかし Goodwin らは，新鮮なウシ血清アルブ ミンからは $\mathrm{S}^{2-}$ は検出されないと述べている.

2-4-2. 結合型イオウ測定のための $\mathrm{S}^{2-}$ に特異的 で高感度な分析法の開発筆者らが MBB 法で測 定した DTT 還元により $\mathrm{S}^{2-}$ を遊離するヒト血清中 のイオウは, ${ }^{27)}$ 結合型で存在している不安定イオウ で，このイオウを結合型イオウと定義した．酸不安 定イオウに比べて結合型イオウは微量で， $\mathrm{S}^{2-}$ に対 して $\mu \mathrm{M} レ$ レルの検出感度が必要である， $\mu \mathrm{M}$ 以下 の $\mathrm{S}^{2-}$ を測定できる方法として，FPD-GC ${ }^{36)}$ や ECD-IC ${ }^{35)}$ などが挙げられる。しかし，前者は夾雑 物の妨害を受け易く，試料を煩雑な前処理により精 製してから適用しなければならず，後者は分離の段 階でのカラムへの吸着及び酸化が起こり易く，低濃 度での直線性に乏しい。汎用されるメチレンブルー 生成による比色法 ${ }^{33,34)}$ は, 定量限界が $1 \times 10^{-5} \mathrm{M}$ 程度で, 感度が不十分である.

筆者らは, $\mathrm{S}^{2-}$ を $p$-phenylenediamine と $\mathrm{FeCl}_{3}$ で 発蛍光性のチオニン誘導体化したのち (Fig. 5) ${ }^{37)}$ HPLC により分離，蛍光検出する高感度で選択性 な $\mathrm{S}^{2-}$ の分析法を開発した. ${ }^{38)}$ HPLC は，チオニン がカチオン性なので（Fig. 5)，アニオン対として $40 \mathrm{mM}$ SDS を含む $50 \mathrm{mM}$ リン酸緩衝液（pH 4.0) とアセトニトリル混液（1：1）を溶離液に用い，逆 相系 C8 カラムで分離し, 蛍光モニター（Ex.600 $\mathrm{nm}, \mathrm{Em} .623 \mathrm{~nm})$ で検出する. $\mathrm{S}^{2-}$ は， $5 \mathrm{nM}-1 \mu \mathrm{M}$ の範囲で直線性を示し，検出限界は $1.5 \mathrm{nM} （ \mathrm{~S} / \mathrm{N}=$ 3）であった。本法はメチレンブルー法に比べ約 15 倍以上，MBB 誘導体化法に比べ約 5 倍高感度で, GC-FPD や IC-ECD に匹敵する。 ヒト赤血球溶血 試料について直接蛍光誘導体化を行い $\mathrm{S}^{2-}$ の検出 を試みたが，検出されなかった。そこで，溶血液を 


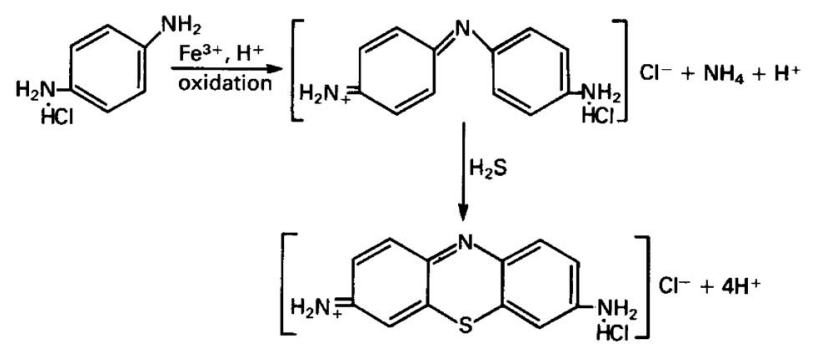

Fig. 5. Fluorogenic Reaction of Sulfide with $p$-Phenylenediamine and $\mathrm{Fe}^{3+}$ to Form Thionine

Conway 拡散セルで処理し酸不安定イオウを測定し たところ，健常人平均 $(n=5)$ で男子 $0.165 \pm 0.025$ $\mu \mathrm{M}$ (packed cells), 女子 $0.151 \pm 0.013 \mu \mathrm{M}$ （packed cells）の酸不安定イオンが検出され，ヒト赤血球中 にも酸不安定イオウが存在することを明らかにし た。しかし，赤血球における $\mathrm{S}^{2-}$ の添加回収率 は, 一部 $\mathrm{S}^{2-}$ がへモグロビンと不可逆的な付加体 を作るか又は赤血球成分の触媒作用で速やかに酸化 されるため 54-61\%と低い值を示した。

2-4-3. 血清中結合型イオウの分析 筆者らは $\mathrm{S}^{2-}$ を高感度で特異的に測定できるチオニンー HPLC と, MBB-HPLCの前処理に用いた連続流れ ガス透析 27) 改良し, 血清中の結合型イオウの測定 に応用し，その存在様態を調べた. ${ }^{39)}$ 結合型イオウ を含む化合物として $\mathrm{S}^{2-}$ 及び元素イオウを結合さ せたウシ血清アルブミン (SBA) を用い, 血清試料 の回収試験を行ったところ, $10 \mathrm{~mm} \mathrm{DTT}$ を用い $\mathrm{pH} 9.0,37^{\circ} \mathrm{C}, 15$ 分の反応でほぼ完全に $\mathrm{S}^{2-}$ が血清 から回収された。検量線の標準物質として, 低分子 結合型イオウ，シスチントリスルフィド (CT) と $\mathrm{NaS}$ で比較したところ 0.1-10 $\mu \mathrm{M}$ の濃度範囲で両物 質の検量線の傾きが一致したので, 結合型イオン測 定の標準物質として NaS を使用した。 CT，元素イ オウを結合させたヒト血清アルブミン（HAS-Sulfur complex）から $\mathrm{S}^{2-}$ がそれぞれ 102\%, 95\% と良 好な回収率で得られ, シスチン, システイン, グル タチオン, $\mathrm{S}_{2} \mathrm{O}_{3}^{2-}, \mathrm{SO}_{3}^{2-}$ からの $\mathrm{S}^{2-}$ の遊離は観察さ れなかった。しかし，これら還元物質はガス透析前 は測定に著しい負の妨害を与えたが，透析後の試料 では完全に妨害は回避された。健常人血清 $(n=10)$ について結合型イオウを測定したところ, 男性で $1.16 \pm 0.09 \mu \mathrm{M} \quad(n=5)$, 女性で $1.07 \pm 0.18 \mu \mathrm{M} \quad(n=$ 5）の測定值が得られ，性差はみられなかった。各
種動物の血清 $(n=5)$ について結合型イオウを測 定したところ, ウサギは $1.55 \pm 0.33 \mu \mathrm{M}$, ラットは $1.88 \pm 0.65 \mu \mathrm{M}$ ，モルモットは $1.65 \pm 0.25 \mu \mathrm{M}$ ，マウ スは $1.55 \pm 0.86 \mu \mathrm{M}$, ウシは $6.18 \pm 0.96 \mu \mathrm{M}$ で, ウ シ以外はヒトと同レベルであった．血清で測定され たイオウ種について分別測定を行ったが, DTT 未 処理の低分子及び高分子画分のいずれからも $\mathrm{S}^{2-}$ は回収されず，遊離及び酸不安定イオウは存在して いなかった。 また，結合型イオウは低分子画分から は回収されず高分子画分にのみ存在していた.

筆者らが測定した血清中の結合型イオウ濃度は, Westley らがシアノリシスで測定したスルファンイ オウ量 $(100 \mathrm{nmol} / \mathrm{g})^{40)}$ に比べて圧倒的に低く, む しろ Sörbo らの TPP 誘導体化 FID-GC で得られた タンパク質結合型イオウ值に近い. ${ }^{36)}$

血清中の結合型イオウの存在形態について, 遊離 $\mathrm{SH}$ 基の保護剤である $N$-ethylmaleimide（NEM）を 用いて調べた。 NEM は過硫化基 $\left(\mathrm{R}-\mathrm{S}-\mathrm{S}^{-}\right)$をマスキ ングし, R-S-S-NEM 付加体を生成し, DTT 還元に よる $\mathrm{S}^{2-}$ の遊離を抑える. Table 2 に標準物質と血 清試料の結合型イオウ測定における NEM の影響を 示す. NEM 処理によって, $S^{2-}$ で処理したヒト血 清（sulfide-treated HAS）は明らかに結合型イオウ が減少していた。血清試料では, 新鮮血から得た血 清が約 $55 \%$, 市販ウシ血清と長期間 $-20^{\circ} \mathrm{C}$ で保存 したヒト血清からはわずかな減少が観察された。こ の結果は, 高分子画分中の結合型イオウのいくらか は過硫化物（例えば protein-S-S ${ }^{-}$）として存在して いることを示唆している.

また，ラット血清試料を $20 \mathrm{mM}$ リン酸緩衝液 （pH 7.1）を用いて, $\mathrm{NaCl}$ 濃度によるステップワ イズでブルーセファロースカラムによる分画を行 い, 結合型イオウの一部はアルブミンに結合して存 在していたが，その量は極めてわずかであった。

3. 結合型イオウを生成又は利用する硫黄転移酵 素の活性測定法

3-1. 3-メルカプトピルビン酸イオウ転移酵素 （3-MST） 3-MST は 1953 年 Meister らによって ラット肝臓から見い出された酵素で, ${ }^{41)}$ 生物界に広 く分布しており, 哺乳動物では肝臓, 腎臓で最も活 性が高く, 赤血球にも活性を示す。細胞内では, 細 胞質とミトコンドリアに分布している. ラット肝臓 から精製した 3-MST は $33 \mathrm{kDa} の$ 単量体で, ラッ 
Table 2. Effect of NEM on Assay for Various Serum Samples

\begin{tabular}{|c|c|c|c|}
\hline \multirow{2}{*}{ Sample } & \multicolumn{2}{|c|}{ Bound sulfur found $\left.(\mu \mathrm{M})^{a}\right)$} & \multirow{2}{*}{ Recovery ratio $(\%)^{b)}$} \\
\hline & With NEM & Without NEM & \\
\hline \multicolumn{4}{|l|}{ Standard ${ }^{c}$} \\
\hline Cystine trisulfide & 6.02 & 6.61 & 91 \\
\hline HAS-sulfur complex & 6.55 & 6.68 & 98 \\
\hline Sulfide-treated HAS & 1.56 & 6.52 & 24 \\
\hline \multicolumn{4}{|l|}{ Serum } \\
\hline Fresh human serum & 0.43 & 0.95 & 45 \\
\hline Human serum stored at $-20^{\circ} \mathrm{C}$ for 3 months & 0.7 & 0.98 & 71 \\
\hline Commercial bovine serum & 3.49 & 3.97 & 88 \\
\hline
\end{tabular}

a) Each assay was carried out three times with the results expressed as means. The concentrations found $(\mu \mathrm{M})$ are the final concentrations after mixing with 50 $\mathrm{mm}$ borate buffer with or without NEM. $b$ ) With NEM/without NEM. $c$ ) Theoretical concentration: $10 \mu \mathrm{M}$ equivalents as $\mathrm{S}^{2-}$.

卜肝臓ロダネーゼのアミノ酸配列と $66 \%$ の相同性 を示す. ${ }^{42)}$ また， ヒト 3-MST とロダネーゼのアミ ノ酸配列の相同性は $59.7 \%$ で, ${ }^{43)}$ 両酵素の構造と機 能の類似性が示唆されている. ${ }^{42)}$ 本酵素は Fig. 1 に 示すように，システインのアミノ基転移反応によつ て生成した 3-MP を $\mathrm{CN}^{-}, \mathrm{SO}_{3}^{2-}, \mathrm{RSO}_{2}^{-}$等の受容体 にイオウ原子を転移させピルビン酸に変換させる反 応を触媒する. 3-MST の生理的機能は，イオウ転 移による $\mathrm{CN}^{-}$の解毒と考えられてきたが，基質特 異性は $\mathrm{SO}_{3}^{2-}, \mathrm{CSA}$ のほうが高く，特に $\mathrm{SO}_{3}^{2-}$ を受 容基質としたとき，生理的な $\mathrm{S}_{2} \mathrm{O}_{3}^{2-}$ の生成系と考 えられている。 また，ferredoxin で代表される鉄一 イオウタンパク質の合成, ${ }^{44)}$ キサンチン酸化酵素で 代表されるモリブデン酵素の活性型への再構成の関 与45)が示唆されている.

3-MST の活性測定法は，3-MP を基質として生成 するピルビン酸か，イオウ原子の受容基質に着目し て測定されている。ピルビン酸に着目した方法とし ては，アルカリ性で 2,4-dinitorophenylhydrazine と 有色のヒドラゾン誘導体とし，その吸光度を 435 $\mathrm{nm}$ で測定する方法46) と, lactate dehydrogenase （LDH）法で測定し，NADH に基づく $340 \mathrm{~nm}$ の吸 光度変化量からピルビン酸量を求める方法47)があ る. 両法は, 精度, 感度, 操作の簡便さの点から生 体試料中の微量な活性測定には不向きである。一 方，受容基質に着目した方法としてイオウ受容基質 に $\mathrm{KCN}$ を用い，生成する $\mathrm{SCN}^{-}$を $\mathrm{Fe}($ III $)$ イオン と有色の $\mathrm{Fe}(\mathrm{SCN})_{3}$ 錯体にし，その吸光度 $(460 \mathrm{~nm})$ を測定して 3-MST 活性求めている. ${ }^{48)}$ この方法は 簡便であるが，感度が低く酵素精製の際のルーチン
分析として用いられている.

筆者らは生体試料中の微量な 3-MST として, 特 にヒト赤血球中の 3-MST に対する高感度な活性測 定法について検討を行つた。測定法の開発に当たつ て，基質である高純度な 3-MP が入手できなかった ので，合成法の検討を最初に行った。従来法 は, ${ }^{49,50)}$ 乾燥 $\mathrm{H}_{2} \mathrm{~S}$ ガスと 3-buromopyruvic acid を用 いて 3-MP を合成していたが，操作が煩雑で収率も 悪く, 純粋で安定な結晶として得ることが難しかつ た。筆者らは，チオール化剤として $\mathrm{H}_{2} \mathrm{~S}$ ガスの変 わりに高純度な $\mathrm{NaHS}$ 結晶を用い, $4{ }^{\circ} \mathrm{C}$ 下 3 bromopyruvic acid と反応させることによって $60 \%$ の収率で，高純度（97.9-98.6\%）な3-MP・Naを 結晶で得ることができた。 ${ }^{51)}$ 合成した 3-MP を用い た赤血球中の 3-MST 活性測定法の原理を以下に示 す. 52)

$$
\begin{aligned}
& \text { 3-MP }+\mathrm{SO}_{3}^{2-} \frac{3-\mathrm{MST}}{\mathrm{DTT}} \text { pyruvate }+\mathrm{S}_{2} \mathrm{O}_{3}^{2-} \\
& \text { excess substrate }+\mathrm{NEM} \longrightarrow \mathrm{NEM} \text { complexes } \\
& \text { pyruvate }+\mathrm{O}_{2}+\mathrm{HOPO}_{3}^{2-} \frac{\mathrm{POP}}{\mathrm{TPP}, \mathrm{Mg}^{2+}} \mathrm{H}_{2} \mathrm{O}_{2} \\
& + \text { acetyl phosphate }+\mathrm{CO}_{2} \\
& 2 \mathrm{H}_{2} \mathrm{O}_{2}+\text { TOOS }+4-\mathrm{AA} \stackrel{\mathrm{POD}}{\longrightarrow} \\
& \text { quinine imine dye }\left(\lambda_{\max } 555 \mathrm{~nm}\right)
\end{aligned}
$$

受容基質として $100 \mathrm{mM} \mathrm{Na}_{2} \mathrm{SO}_{3}$ を用い， $50 \mu \mathrm{l}$ の 溶血液 $\left(2.5 \times 10^{4}\right.$ 赤血球 $\left./ \mu \mathrm{l}\right)$ と反応促進剤である $10 \mathrm{mM}$ DTT を含む供与基質 $25 \mathrm{~mm} 3-\mathrm{MP}$ を加える （反応 $\mathrm{pH} 8.0$ )。 反応混合液を $37^{\circ} \mathrm{C}$ で 15 分間イン キュベートしたのち，0.11 M NEM を加え反応を停 
止する. 5 分後, 発色剂である 4-aminoantipyrine (4-AA ) と sodiumu N-ethyl-N- ( 2-hydroxy-3-sulfopropyl)-m-toluidine (TOOS), thiamine pyrophosphate (TPP), $\mathrm{Mg}^{2+}, \mathrm{KH}_{2} \mathrm{PO}_{4}$, peroxidase (POD) と pyruvate oxidase (POP) を含む発色溶液 $(\mathrm{pH}$ 6.5）を加え， $37^{\circ} \mathrm{C}$ で 10 分間インキュウベートし たのち， $555 \mathrm{~nm}$ における吸光度を測定し，3-MST 活性を求める。NEM は，過剩量の基質 3-MP と $\mathrm{SO}_{3}^{2-}$ を反応系から取り除くために加える。 TOOS と 4-AA は POD 存在下, 過酸化水素と酸化的に縮 合して紫色のキノンイミン色素（555 nm）を生成 する.

本法は従来法である LDH 法 ${ }^{47)}$ より約 15 倍高感 度で, $3-M S T$ 活性が $2.5 \times 10^{4}$ 赤血球 $/ \mu \mathrm{l}$ 溶血液で測 定できる. 健常人ヒト赤血球中の 3-MST 活性を測 定したところ，平均で 64 units/10 10 赤血球 $(n=30)$ が得られ，この值は LDH 法で測定した Valentine と Frankenfeld ${ }^{47)}$ の結果と同レベルであった。

3-2 ロダネーゼ ロダネーゼ（thiosulfate : cyanide sulfurtransferase) は $\mathrm{S}_{2} \mathrm{O}_{3}^{2-}$ のスルファン イオウを受容体である $\mathrm{CN}^{-}$に与え, $\mathrm{SCN}^{-}$を生成 する反応を触媒する酵素とて，1933 年 Lang らによ つて発見された。ロダネーゼはあらゆる生物体に広 く分布しているが, 哺乳動物の組織では 3-MST と 同じように肝臓と腎臓に最も高い活性を示し，その 活性はすべてミトコンドリアマトリックスに存在し ている.

ロダネーゼの生体での第一の働きは, シアン化物 の解毒であると考えられてきた。しかしミトコンド リア酵素であるロダネーゼは，その供与体基質であ る $\mathrm{S}_{2} \mathrm{O}_{3}^{2-}$ がミトコンドリア内膜を通過し難く, シ アンの解毒作用をロダネーゼの第一の働きとする見

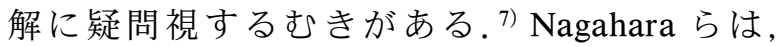
3-MST とロダネーゼの働きの違いを, ウサギ由来 の抗-3-MST 抗体を用いた生化学的及び免疫組織学 的手法でラットの組織, 細胞, 小器官での分布を調 ベ，3-MST は細胞質とミトコンドリアの両方に局 在していることを明らかにした. ${ }^{53)}$ そして $\mathrm{CN}^{-}$の 解毒は，まず細胞質で 3-MST によって $\mathrm{SCN}^{-}$に解 毒され，解毒されず残った $\mathrm{CN}^{-}$はミトコンドリア に入り，3-MST とロダネーゼの共同作業で解毒す る説を提案している. ${ }^{54)}$ もう1つの働きとして， ロ ダネーゼはいろいろなスルファン供与体がくると
$\mathrm{SO}_{3}^{2-}$ と反応して $\mathrm{S}_{2} \mathrm{O}_{3}^{2-}$ を生成することから， $\mathrm{S}^{2-}$ の無毒化を触媒することが考えられている. ${ }^{7)}$

本酵素と病態との係わりとしては，先天性のシア ン解毒能欠損症である Leber 病（視神経萎縮症候 群) 55) との関係が言われてきたが，組織の違いによ ってロダネーゼ活性は正常值を示したり低值であっ たりと一定の見解が得られていない。現在では， Leber 病はミトコンドリア DNA の突然変異によっ て引き起こされる疾患として認識されている.

これらロダネーゼ研究におけるロダネーゼの活性 測定法としては, 供与基質として $\mathrm{Na}_{2} \mathrm{~S}_{2} \mathrm{O}_{3}$, 受容基 質として KCN を用い，生成する $\mathrm{SCN}^{-}$を $\mathrm{Fe}(\mathrm{III})$ 錯体として $460 \mathrm{~nm}$ で比色定量する Sörbo 法 ${ }^{56)}$ が最 も広く用いられている。しかし Sörbo 法は，0.1 $\mu$ mole 以下の $\mathrm{SCN}^{-}$は測定できず，感度の点で血 清等の低活性試料への応用は困難である. その他,

Sörbo 法で生成する $\mathrm{SO}_{3}^{2-}$ に注目し, 電子伝達物質 とラジカルを発生させ, nitroblue tetrazolium （NTB）を還元して生成するホルマザン色素を530 $\mathrm{nm}$ で測定する高感度な測定方法が知られてい る. ${ }^{57)}$ 本法では $0.5-2 \mathrm{nM}\left(5-100 \mu \mathrm{M}\right.$ の $\left.\mathrm{SO}_{3}^{2-}\right)$ のロ ダネーゼが測定でき, Sörbo 法より約 3 倍高感度で あるが，生成する色素が不溶性のため定量性に欠け る. 実用的に使われているのは Sörbo 法のみで, 血液など低活性試料には感度が不十分であった，筆 者らは, 供与基質として $\mathrm{S}_{2} \mathrm{O}_{3}^{2-}$ 以外に 4 種の thiosulfonate 誘導体, methanethiosulfonate (MTS), ethanethiosulfonate (ETS), benzenethiosulfonate (BTS)， p-toluenethiosulfonate（TTS）を合成し， それらの反応性を調べ, MTS が $\mathrm{S}_{2} \mathrm{O}_{3}^{2-}$ に比べ約 95 倍反応速度が早いことを見い出した. しかし，イオ ウの $\mathrm{CN}^{-}$への自発的転移も $\mathrm{S}_{2} \mathrm{O}_{3}^{2-}$ に比べて約 12 倍増大した。しかし， ロダネーゼの安定剤でかつ賦 活化剂として加えた DTT が MTS の自発的イオウ の転移を抑えることが分かり，MTS を用いる高感 度なロダネーゼの活性測定法を次のように確立し た. ${ }^{58)}$

$$
\begin{aligned}
& \mathrm{CH}_{3} \mathrm{SO}_{2} \mathrm{~S}^{-}(\mathrm{MTS})+\mathrm{CN}^{-}+\mathrm{DTT} \underset{\mathrm{SCN}^{-}+\mathrm{CH}_{3} \mathrm{SO}_{2}^{-}}{\longrightarrow} \\
& \mathrm{CN}^{-}+\mathrm{HCHO} \longrightarrow \mathrm{H}_{2} \mathrm{C}(\mathrm{OH}) \mathrm{CN} \\
& \mathrm{SCN}^{-}+\mathrm{Fe}\left(\mathrm{ClO}_{4}\right)_{3} \longrightarrow \mathrm{Fe}(\mathrm{SCN})_{3}
\end{aligned}
$$$$
\text { (orange, } \lambda_{\max } 460 \mathrm{~nm} \text { ) }
$$ 
受容基質として $62 \mathrm{mM} \mathrm{KCN}$ を用い， $0.03 \mathrm{mM}$ DTT と供与基質 $0.017 \mathrm{mM} \mathrm{MTS}$ を加える（反応 $\mathrm{pH} 8.6 ） .25^{\circ} \mathrm{C}$ で 1 分間プレインキュベートしたあ と, 試料を加える。 反応は $25^{\circ} \mathrm{C}$ で 5 分間行う。木 ルムアルデヒドで反応を停止したのち，還元剤とし $\tau \mathrm{Na}_{2} \mathrm{~S}_{2} \mathrm{O}_{3}$ と発色剂 $\mathrm{Fe}\left(\mathrm{ClO}_{4}\right)_{3}$ を含む $\mathrm{HClO}_{4}(28$ \%）水溶液を加える，反応混合液を遠心分離後，赤 色の $\mathrm{Fe}(\mathrm{SCN})$ 3 錯体を含む上澄液の吸光度を 460 $\mathrm{nm}$ で測定し，ロダネーゼ活性を求める。本法は, Sörbo 法に比べ約 95 倍高感度で，健常人ヒト血清 ロダネーゼ活性測定に応用したところ，初めてその 活性を測定することができ, $20.9 \pm 20.0$ units/1（n= 31）の正常值を得た。本法は chaotropic 剂である $\mathrm{HClO}_{4}$ 液を用いることで，血清アルブミンと結合 した（約 $40 \%$ ）酵素反応で生成した $\mathrm{SCN}^{-}$を完全 に遊離させる利点を有している.

3-3. $\quad \gamma$-シスタチオナーゼ（ $\gamma$-CST） $\quad \gamma$-CST は哺乳動物の組織中に広く分布し, 肝臓で高活性を 示す. ${ }^{59)} \gamma$-CST の哺乳類細胞における主たる機能 は，メチオニン代謝の trans-sulfuration pathwayに おいて，シスタチオニンを分解触媒し L- システイ ンを生成するとともに，L- システインの最終段階 を触媒する（Fig. 1)。しかし，本酵素は multifunctional lyase で，シスタチオニンと同じょうに多く のアミノ酸の $\beta$-又は $\gamma$-脱離反応を触媒する。 $\gamma$ CST はシスチンを非対照的に分解して，チオシス テイン，ピルビン酸とアンモニアを生成する .

$\gamma$-CST 活性は, L-homoserine から生成する 2ketobutyric acid をアルカリ性で 2,4-dinitrophenylhydrazine と反応させ，赤色の hydrazone とし，そ の吸光度を $515 \mathrm{~nm}$ で測定するか, ${ }^{60)}$ シスタチオニ ンから生成するシステインを酸性ニンヒドリンで発 色させ，紅色の生成物を $560 \mathrm{~nm}$ で吸光度を測定 ${ }^{61)}$ するルーチン法が使われている，Ohmori らは, ${ }^{62)}$ 基質にシスタチオニンを用い，生成した 2-ketobutyric acid 蛍光誘導体化試薬 1,2-diamino-4,5dimethoxybenzen で quinoxalline 誘導体とし，プレ カラム蛍光誘導体化 HPLC で高感度にラット肝臓 中の $\gamma$-CST 活性を測定している。 2 つの比色法 は，操作の過程で遠心分離や加熱が加わり，また HPLC 法は高感度でケト酸の分離定量には適して いるが，迅速性にかけルーチン法としては簡便さに かける。
筆者らはこれらの点を考慮し，簡便で高感度な $\gamma$-CST 活性測定法を粗精製ラット肝臓 $\gamma$-CST を用 い検討した，基質として L-homoserine の活性を $100 \%$ としたとき，シスタチオニンの相対活性は $20.0 \%$ ，シスチンは $12.1 \%, \beta$-chloro-L-alanine（ $\beta$ CA）は $130.0 \%$ で， $\beta$-CA の $\gamma$-CST に対する相対 活性が L-homoserine より高いことが分かった。 $\beta$ CA は，生成物としてピルビン酸を与えるので，基 質として $\beta$-CA を用い，POP と POD の酵素を組み 合わせた 3-MST 活性測定システムを改良し（3-1 参照)， ${ }^{52)}$ 高感度な活性測定法を確立した。 ${ }^{63)}$

$$
\begin{gathered}
\mathrm{Cl}-\mathrm{CH}_{2} \mathrm{CH}\left(\mathrm{NH}_{2}\right) \mathrm{COOH}\left(\beta \text {-CA) } \frac{\gamma \text {-CST }}{\mathrm{PLP}}\right. \\
\mathrm{CH}_{3} \mathrm{COCOOH}+\mathrm{NH}_{3}+\mathrm{HCl} \\
\text { Enzyme-SH (active } \gamma \text {-CST) }+4 \text {-PDS } \longrightarrow \\
\text { Enzyme-S-4-tyiopyridine (inactive } \gamma \text {-CST) }
\end{gathered}
$$$$
+4 \text {-thiopyridone }
$$$$
\mathrm{CH}_{3} \mathrm{COCOOH}+\mathrm{O}_{2}+\mathrm{HOPO}_{3}^{2-} \frac{\mathrm{POP}}{\mathrm{TPP}, \mathrm{Mg}^{2+}}
$$$$
\mathrm{H}_{2} \mathrm{O}_{2}+\mathrm{CH}_{3} \mathrm{COOPO}_{3}^{2-}+\mathrm{CO}_{2}
$$$$
\mathrm{H}_{2} \mathrm{O}_{2}+\text { DA-64 (leuco dye) } \stackrel{\text { POD }}{\longrightarrow}
$$$$
\text { Bindschedler's Green }\left(\lambda_{\max } 727 \mathrm{~nm}\right)
$$

酵素反応は，補酵素ビタミン $\mathrm{B}_{6}$ （PLP）の存在 下, $\mathrm{pH} 8.0,37^{\circ} \mathrm{C}$ で 15 分間行う。反応停止剂には, SH 基のマスキング剂を種々検討した結果， $\gamma$-CST の自殺的基質である D,L-propargylglycine（PG）と 同様に $100 \%$ 活性を阻害した SH 基修飾剤である 4,4-dithiopyridine (4-PDS) を用いた。生成したピ ルビン酸は，POPで過酸化水素に酸化され，POD と $N$ - (carboxymethylaminocarbonyl) -4,4' -bis (dimethylamino)-diphenylamine (leuco type, DA-64) を 酸化し, Bindschelder'S Green $\left(\varepsilon=8.5 \times 10^{4}, \quad \lambda_{\text {max }}\right.$ $727 \mathrm{~nm}$ ) を生成させ, 緑色色素の吸光度を $\gamma$-CST 活性として測定する。

本法は， 0.1-1.6 $\mu \mathrm{g}$ のラット肝臓粗精製 $\gamma$-CST 活性が測定でき, hydrazine 法に比べ約 10 倍高感度 である。本法を用いてラット肝臓と腎臓 $(n=10)$ の $\gamma$-CST 活性を測定したところ，各々 $8.03 \pm 2.43$ unit/g wet weight, $3.85 \pm 0.40 \mathrm{unit} / \mathrm{g}$ wet weight $の$ 結 果を得た。本法は，結合型イオウと $\gamma$-CST に依存 している脱硫経路の研究や, $\gamma$-CST の生理機能に 関する研究に有効である. 


\section{4. 結合型イオウの生理学的機能評価}

筆者らが開発したチオニン -HPLC 法による $\mathrm{S}^{2-}$ (2-4-2 項) ${ }^{38)}$ と結合型イオウ (2-4-3 項) ${ }^{39)}$ の測定法 及びスルファンイオウを生成するイオウ転移酵素, 3-MST (3-1 節) ${ }^{52)}$ と $\gamma$-CSA (3-3 節) ${ }^{63)}$ の活性測定 法を用いて結合型イオウの生理的機能を評価した。

4-1. ラット組織及び細胞内結合型イオウと酸不 安定イオウの分布 ラット各組織の湿重量当たり の結合型イオウ, 酸不安定イオウの含量と 3-MST 及び $\gamma$-CST 活性を Table 3 に示す. ${ }^{64)}$ DTT 還元で 得られた総遊離イオウ含量は腎臓が一番多く，その 約 $90 \%$ は結合型イオウであった。心蔵の総遊離イ オウ含量は腎臓についで多く，そのほとんどは酸不 安定イオウで, 結合型イオウは検出限界以下（1 $\mathrm{nmol} / \mathrm{g}$ 以下）であった。肝蔵，脳，脾臓の総量は 相対的に似ており，その 60-80\%は結合型イオウが 占めている. 湿重量 $1 \mathrm{~g}$ 当たりの結合型イオウ量 は，タンパク質結合型イオウ $\left(\mathrm{S}^{0}\right)$ を測定した Sörbo らの結果 ${ }^{36)}$ と比較すると, 腎臓で約 12 倍, 脾臓で約 8 倍, 肝臓で約 4 倍と高值を示したが, 脳 では約半分，心臓（Sörbo ら：35.6 nmol/g）では 結合型イオウは検出されなかつた。筆者らが測定対 象とする結合型イオウには, 疎水性の $\mathrm{S}^{0}$ タイプ (非電荷型) のイオウ原子ばかりでなく，タンパク 質のシステイン残基に結合した高分子過硫化型，チ オシステインなどの低分子過硫化型，シスチントリ スルフィドなどの多硫化型が DTT 還元で $\mathrm{S}^{2-}$ を遊 離する結合型イオウで (Fig. 2), Sörbo らが心臓で 得た $\mathrm{S}^{0}$ 量は，操作に長時間を要するため，酸不安 定イオウが酸化されてしまった結果と考えられる. 結合型イオウは血液中よりも藏器中に高濃度で存在 し，酸不安定イオウも常在していることを明らかに
した。一方, 結合型イオウ生成に関与する 3-MST と $\gamma$-CST 活性は肝臓と腎臟で高く, 他の臟器では わずかしか観察されなかった。特に $\gamma$-CST は, 肝 臓と腎臓にのみ活性が観察された。

Table 4 は，結合型イオウ含量が高く，3-MST と $\gamma$-CST 活性が高い（Table 3）肝臓と腎臓の結合型 イオウ, 酸不安定イオウ, 3-MST, $\gamma$-GST の細胞内 分布を示している. 肝臓, 腎臓全抽出物の総遊離イ オウ量の約 42-45\%は粗サイトゾール画分に，21$27 \%$ は粗ミトコンドリア画分に存在している. 総遊 離イオウのうち, 結合型イオウのほとんどは粗サイ トゾール画分（肝臓：90\%以上，腎臓：70\%以上) に局在し, 結合型イオウの生成, 貯蔵の場. 酸不安 定イオウは主に粗ミトコンドリア画分に局在してい る。一方，肝蔵全抽出物の 3-MST 活性の約 $60 \%$ は 粗ミトコンドリア画分に，40\%が粗サイトゾール画 分に局在し，腎臓の場合は，約 $70 \%$ が粗サイト ゾール画分に局在している。 $\gamma$-CST 活性は両組織 とも主に粗サイトゾール画分に局在している.

結合型イオウがサイトゾール画分に多いという結 果は，結合型イオウの生成，貯蔵の場がサイトゾー ルであることが推測される．また，酸不安定イオウ が，組織では心臓，細胞内小器官ではミトコンドリ ア画分に多く存在するという結果は，そのほとんど が鉄一イオウタンパク質を構成するイオウ原子の供 給源と考えられる. ${ }^{44,65)}$

肝臓，腎臓サイトゾール画分のゲルろ過クロマト グラフィーより，結合型イオウの多くは高分子画分 に存在していた（肝蔵：推定分子量 45 万と 5 万, 腎藏：5 万)。また腎臓においては，高分子画分の ほかに分子量 1 万以下の低分子画分に非タンパク質 の結合型イオウが高分子型と同程度存在していた.

Table 3. Tissue Distribution of the Bound and Acid-Labile Sulfur and the Enzyme Activities Related to the Desulfuration Pathway in $\operatorname{Rats}^{a}$

\begin{tabular}{|c|c|c|c|c|c|}
\hline \multirow{2}{*}{ Tissue } & \multicolumn{3}{|c|}{ Releasable sulfur } & \multirow{2}{*}{$\left.3-\mathrm{MST}^{c}\right)(\mathrm{U} / \mathrm{g})$} & \multirow{2}{*}{$\gamma-\mathrm{CST}^{c)}(\mathrm{U} / \mathrm{g})$} \\
\hline & Total $(\mathrm{nmol} / \mathrm{g})$ & Bound $^{b)}(\mathrm{nmol} / \mathrm{g})$ & Acid-labile (nmol/g) & & \\
\hline Liver & $66.74 \pm 8.89$ & $40.76 \pm 11.42$ & $25.97 \pm 2.96$ & $472 \pm 55.6$ & $8.03 \pm 2.43$ \\
\hline Kidney & $363.9 \pm 104.8$ & $324.1 \pm 100.7$ & $39.85 \pm 7.36$ & $425 \pm 80.7$ & $3.85 \pm 0.40$ \\
\hline Heart & $128.6 \pm 17.8$ & Not detected & $129.3 \pm 16.5$ & $95.7 \pm 17.3$ & $0.04 \pm 0.02$ \\
\hline Brain & $31.05 \pm 6.24$ & $18.53 \pm 8.09$ & $12.51 \pm 2.13$ & $38.7 \pm 5.01$ & $0.09 \pm 0.03$ \\
\hline Spleen & $40.91 \pm 13.81$ & $34.06 \pm 14.21$ & $6.830 \pm 0.63$ & $64.8 \pm 6.43$ & Not detected \\
\hline
\end{tabular}

a) All values represent the means \pm S.D. for triplicate determinations on tissues from five male rats. $b$ ) Bound sulfur $=$ total sulfur-acid-labile sulfur. $c$ ) Unit $=$ $\mu \mathrm{mol}$ product/min. 


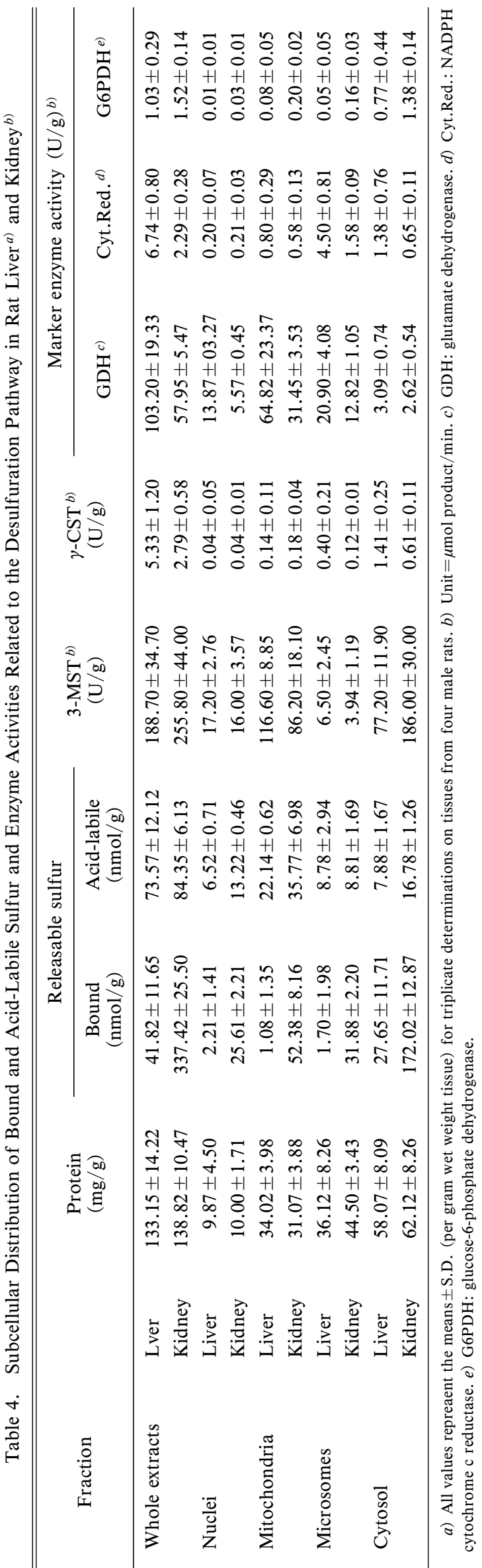

この低分子画分の成分が腎臟に特異的であるかは現 段階では不明であるが，結合型イオウの半分近くが 低分子成分として存在していることは興味深い.

4-2. 結合型イオウ生成系の解析 結合型イオ ウが生体内で生成，貯蔵，利用されるまでの移行過 程とその形態について知見を得るため，ラット組織 及び細胞小器官における脱硫活性を L-システインを

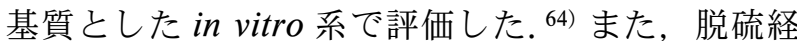
路に関与する 3-MST と $\gamma$-CST の活性との関係につ いても調べた。脱硫活性は，DTT 還元により組織 湿重量 $1 \mathrm{~g}$ 当たり 1 分間に生成する $\mathrm{S}^{2-}$ 量とした. ラットの各組織より調製した抽出液について，シス テインを基質とした脱硫活性を Table 5 に示す．脱 硫活性（ $\mathrm{S}^{2-}$ の生成）は， $\gamma$-CST 活性に比例して （Table 3）肝臓が最も高く，ついで腎臓であった. また，ラット肝臟及び腎臓抽出物のシステイン添加 による $\mathrm{S}^{2-}$ の生成は， $\gamma$-CST の自殺的阻害剂であ る PG で 80-90\%阻害されたが，他の組織では阻害 されなかった。一方, cysteine aminotransferase を 含む 3-MST 系の競合的阻害剤である L- アスパラギ ン酸の添加では, 肝臓，腎臟の脱硫活性はなんら阻 害されなつかたが，脳での脱硫活性を約 $40 \%$ 阻害 した（Table 5)。このように，生体における脱硫活 性は，3-MST 系よりも $\gamma$-CST 系に依存していると 思われる. ${ }^{66)}$

システインを添加した組織及び細胞抽出液中の遊 離 $\mathrm{S}^{2-}$ 量を測定したが， $\mathrm{S}^{2-}$ の遊離は非常に少なく, DTT 還元でその量が増加し，ほとんどが結合型で 存在していた。他の組織や小器官にも相当量の酸不 安定イオウ又は結合型イオウが存在している（Tables 3 and 4)。また, 腎臓中の総遊離 $\mathrm{S}^{2-}$ は肝臓よ り約 5 倍多いのに対し（Table 3)，脱硫活性は肝臓

Table 5. Effect of Propargylglycine and Aspartate on the Sulfide Production Capacity from Cysteine in Rat Tissues ${ }^{a}$

\begin{tabular}{lccr}
\hline \hline \multirow{2}{*}{ Tissues } & \multicolumn{3}{c}{ Released sulfide $(\mathrm{nmol} / \mathrm{g} / \mathrm{min})$} \\
\cline { 2 - 4 } & Control & $\begin{array}{c}\text { + Propargylglycine } \\
\text { (\% control) }\end{array}$ & $\begin{array}{c}\text { + Aspartate } \\
\text { (\% control) }\end{array}$ \\
\hline Liver & 38.0 & $8.59(22.6 \%)$ & $36.29(95.5 \%)$ \\
Kidney & 18.9 & $2.22(11.7 \%)$ & $17.91(94.8 \%)$ \\
Brain & 1.78 & $1.94(109.0 \%)$ & $1.02(57.5 \%)$ \\
Heart & 1.52 & $1.63(107.2 \%)$ & $1.10(72.9 \%)$ \\
Spleen & 0.89 & $1.31(147.2 \%)$ & $0.69(78.1 \%)$ \\
\hline
\end{tabular}

a) Average of three rats. 
の半分以下である (Table 5)。この結果は, 生体内 で内因性イオウに対する輸送機構が存在することが 推測される。 すなわち, 肝臓のサイトゾールで生成 した $\mathrm{S}^{2-}$ は，速やかに結合型イオウに変換され， 他の組織又は細胞間画分に輸送される。ミトコンド リアに輸送されたイオウは，イオウ転移酵素，例え ばロダネーゼの作用で鉄一イオウクラスター中に取 り込まれるかもしれない。 ${ }^{67)}$ サイトゾール画分に保 持された結合型イオウは，貯蔵のためにタンパク質 に非特異的に結合しているばかりでなく，サイト ゾール酵素に有意に取り込まれ，ある種の酵素の活 性化に関与する (後述).

4-3. 結合型イオウによる鉄一イオウクラスター の再構成フェレドキシン（Fd）に代表される 酸不安定イオウを含む鉄一イオウタンパク質は, ク ロロプラストやミトコンドリアに局在している電子 伝達系に機能的に結び付いている．鉄一イオウタン パク質の補欠分子族形成機構の研究は，ほとんど in vitro での再構成系で行われているが，酸不安定 イオウの生理学的供給源はいまだ不明確である。哺 乳類の組織や体液に広く分布している還元一不安定 イオウ ${ }^{27,39,64)}$ は簡単に $\mathrm{S}^{2-}$ に変換される。一方，イ オウ転移酵素である 3-MST やロダネーゼは高等動 物の鉄一イオウクラスターの形成に関与していると 考えられているが，生理的基質には疑問が残ってい る.

筆者らは，結合型イオウが非へム鉄一イオウタン パク質の酸不安定イオウとして利用されるか，ホウ レン草の Fd を用いる再構成系で検討した. ${ }^{68)}$ 再構 成反応で形成される鉄一イオウクラスターは不安定 で，鉄一イオウタンパク質は微量であるため，再構 成反応生成物は，疎水モードの TSK-GEL phenyl 5 $\mathrm{PW}$ カラムを用い, 硫酸アンモニウム含有 $0.1 \mathrm{M}$ リ ン酸緩衝液（pH 7.0） でイソクラテックで迅速に分 離した。結合型イオウの低分子モデル化合物として $\mathrm{CT}$ ，高分子化合物として SBA を用い，ホウレン草 apo-Fd で再構成反応を行った．Figure 6 は再構成 反応を行った反応液のクロマトグラフムを示してい る. SBA 及び CT 由来の結合型イオウは，還元物 質ジヒドロリポ酸（DHL) ${ }^{69)}$ と $\mathrm{Fe}(\mathrm{III})$ の存在下, 極めて効果的にホウレン草由来の 2 分子種のフェレ ドキシン，Fd I , Fd II の形成に利用された [Fig. 6 (C, D) ]。 クラスターの $100 \%$ 再構成は, CT 0.25
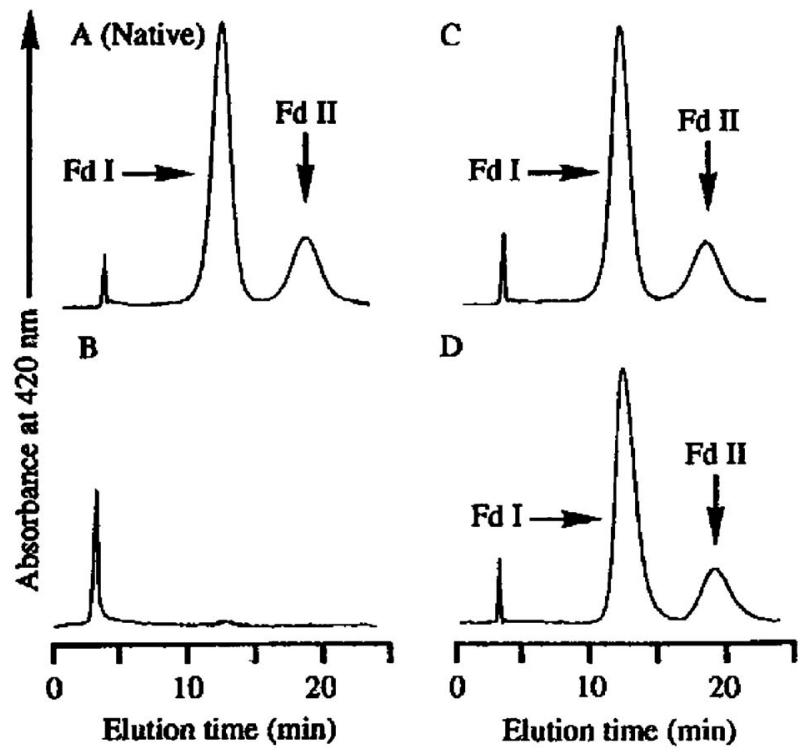

Fig. 6. Typical Chromatograms of Native Ferredoxin in Solution and Reconstitution Reaction Mixtures Using Cystine Trisulfide (CT) or Sulfur-bound Albumin (SBA) as a Sulfur Donor

(A) : standard solution containing $1 \mathrm{nmol}$ of purified native ferredoxins from spinach, (B): reaction mixture containing $0.1 \mathrm{~mm}$ apoferredoxin, $5 \mathrm{~mm}$ D,L-dihydrolipoate (DHL) and $1 \mathrm{~mm}$ ferric nitrate (for blank), (C): 0.25 mM CT added to mixture (B), (D) : $1 \mathrm{~mm}$ SBA added to mixture (B). The reaction mixtures were incubated for $60 \mathrm{~min}$ at $37^{\circ} \mathrm{C}$. All samples were dissolved in $0.15 \mathrm{M}$ Tris/ $\mathrm{HCl}$ buffer, $\mathrm{pH}$ 7.3.

mM，SBA $1 \mathrm{mM}$ を用いたときに得られた。 $0.25 \mathrm{mM}$ 以上の CT 添加で再構成率が低下したことから, 過 剰な $\mathrm{S}^{2-}$ はクラスター形成を妨害する。したがっ て，高分子型である SBA の方が安定な供与体であ り，効率的に利用されると考えられる.

In vitro の $\mathrm{Fd}$ 再構成実験で, 効果的な還元剤は DHL であったが，GSH やシステインも CT や SBA から $\mathrm{S}^{2-}$ を遊離する。再構成系で用いた Apo$\mathrm{Fd}$ は, TCA 処理でクラスターを分離除去して調製 したので，その処理でシステイン残基が酸化された と考えられる。In vivoにおける Fd の生合成にお いて，Apo-Fd はシステイン残基が酸化されていな い状態でクラスターを獲得しているとすれば DHL ほどの還元力は必要なく，その場合，GSH などが 還元物質として Fd 生合成に関与する可能性も否定 できない.

In vitro での $\mathrm{Fd}$ 再構成の実験結果から，恐らく $\gamma$-CST によってサイトゾールで作られた結合型イ オウ (Tables 3 and 4 : 例えばチオシステイン) ${ }^{64)}$ がミトコンドリアに移行し，鉄一イオウセンター形 成に使われると考えられる。 
4-4. 結合型イオウの酵素活性修飾タンパク 質の SH 基とジスルフィド間のチオール／ジスルフ イド交換反応が酵素活性を調節することはよく知ら れている，筆者らは，結合型イオウが肝臓サイト ゾール中の解糖系と糖新生系酵素の活性にどのよう な影響を及ぼすか， $\gamma$-CST-シスチン系で生成する 結合型イオウとシスチンと同じジスルフィドである 酸化型グルタチオン（GSSG）の効果を比較するた め，9種のサイトゾール酵素について，それらの活 性変化を測定した（Table 6).70)

シスチン添加で活性が低下したのは，6-phosphofructokinase (PFK) と pyruvate kinase (PK) であった。一方, GSSGは，glucose-6-phosphate dehydrogenase と hexokinase（HK）の活性をシス チンよりも強く阻害した。 シスチン添加により低下 した PFK と PK 活性は, DTT の添加によって PFK はほぼ完全に，PK は約 $80 \%$ 活性が回復した
(Table 7)。また， $5 \mathrm{mM} \mathrm{GSH} の$ 処理で $82 \%, 0.2$ mM NADPH の処理で $78 \%$ の活性が回復し，両者 の組み合わせでは GSH 処理と変わらなかったこと から, thioltransferase, thioredoxin reductase 又は glutathione reductase が活性復活に関与することが 示唆された. ${ }^{71)}$ また，精製した PFK 活性は，CT （10 $\mu \mathrm{M}$ 以上）の添加で顕著な活性の低下が起こり, 60 分の反応で $10 \%$ まで活性が低下した。ラット肝 臓から精製した $\gamma$-CST，精製 PFK とシスチンを用 いた再構成系で PFK 活性は $\gamma$-CST 濃度に依存的に 低下した [Fig. 7(A) ]。また，この活性の低下は， DTT でほぼ完全に回復し, 再構成系で PG 処理し た $\gamma$-CST の添加では，PFK 活性の低下は観察され なかった [Fig. 7(B)].

これまで，酵素 SH 基のジスルフィド化合物によ る活性修飾は，主に GSH 濃度に依存する非特異的 な反応であることから，生体調節という観点からは

Table 6. Effects of Disulfide Compounds on Various Enzymes in Rat Liver Cytosol ${ }^{a}$

\begin{tabular}{|c|c|c|c|}
\hline \multirow{2}{*}{ Enzyme } & \multicolumn{3}{|c|}{ Remaining activity \% (mean \pm S.D.) } \\
\hline & Control & Cystine $^{b)}$ & $\mathrm{GSSG}^{b)}$ \\
\hline Hekisokinase & $75.7 \pm 17.1$ & $84.2 \pm 12.8$ & $55.2 \pm 21.4$ \\
\hline Fructose-1,6-bisphosphatase & $119.2 \pm 15.7$ & $96.9 \pm 6.8$ & N.T. \\
\hline 6-Phosphofructokinase & $80.6 \pm 9.3$ & $40.4 \pm 10.0^{* \sharp}$ & $61.7 \pm 7.68$ \\
\hline Fructose-1,6-bisphosphate aldolase & $95.6 \pm 6.5$ & $89.5 \pm 5.1$ & $99.4 \pm 8.4$ \\
\hline Phospho enol pyruvate carboxykinase & $99.4 \pm 11.6$ & $96.3 \pm 11.6$ & N.T. \\
\hline Pyruvate kinase & $94.1 \pm 0.9$ & $19.6 \pm 7.4^{* \#}$ & $92.4 \pm 0.9$ \\
\hline Glucose-6-phosphate dehydrogenase & $75.3 \pm 2.0$ & $61.8 \pm 8.1^{*}$ & $55.1 \pm 9.8^{*}$ \\
\hline Adenylate kinase & $101.2 \pm 8.6$ & $93.5 \pm 12.2$ & N.T. \\
\hline Alcohol dehydrogenase & $89.4 \pm 4.0$ & $81.9 \pm 2.8$ & $84.9 \pm 4.7$ \\
\hline
\end{tabular}

Table 7. Inhibitory Effects of Trisulfide Derivatives and Referential Compounds on Lipid Peroxidation induced by Various Systems

\begin{tabular}{lrrrrr}
\hline \hline \multirow{2}{*}{$\begin{array}{c}\text { Induced } \\
\text { system }\end{array}$} & \multicolumn{5}{c}{ Inhibition $^{a)}$} \\
\cline { 2 - 6 } & \multicolumn{1}{c}{$\mathrm{TC}$} & \multicolumn{1}{c}{$\mathrm{NT}$} & \multicolumn{1}{c}{$\mathrm{CT}$} & Cystine & \multicolumn{1}{c}{ Cysteine } \\
\hline $\mathrm{Fe}^{2+}$-Asc & $3.6 \pm 0.82$ & $-1.6 \pm 1.31$ & $18.9 \pm 5.56$ & $8.6 \pm 6.15$ & $1.9 \pm 4.72$ \\
$\mathrm{CCl}_{4}$ & $47.8 \pm 1.97$ & $2.0 \pm 1.00$ & $29.8 \pm 5.90$ & $6.2 \pm 2.89$ & $10.0 \pm 3.76$ \\
$t$-BuOOH & $34.8 \pm 4.66$ & $3.6 \pm 0.67$ & $14.4 \pm 1.72$ & $4.7 \pm 5.15$ & $5.1 \pm 2.37$ \\
\hline
\end{tabular}

TC: thiocyclam, NT: nereistoxin, CT: cystine trisulfide. Microsomal suspensions were preincubated at $37^{\circ} \mathrm{C}$ for $5 \mathrm{~min}$ in the presence or absence (control) of $100 \mu \mathrm{M}$ test samples, and each assay of lipid peroxidaton was performed at $37^{\circ} \mathrm{C}$. a) (\%) Inhibition of the accumulation rate of TBS-RS as compared to controls performed in parallel. 

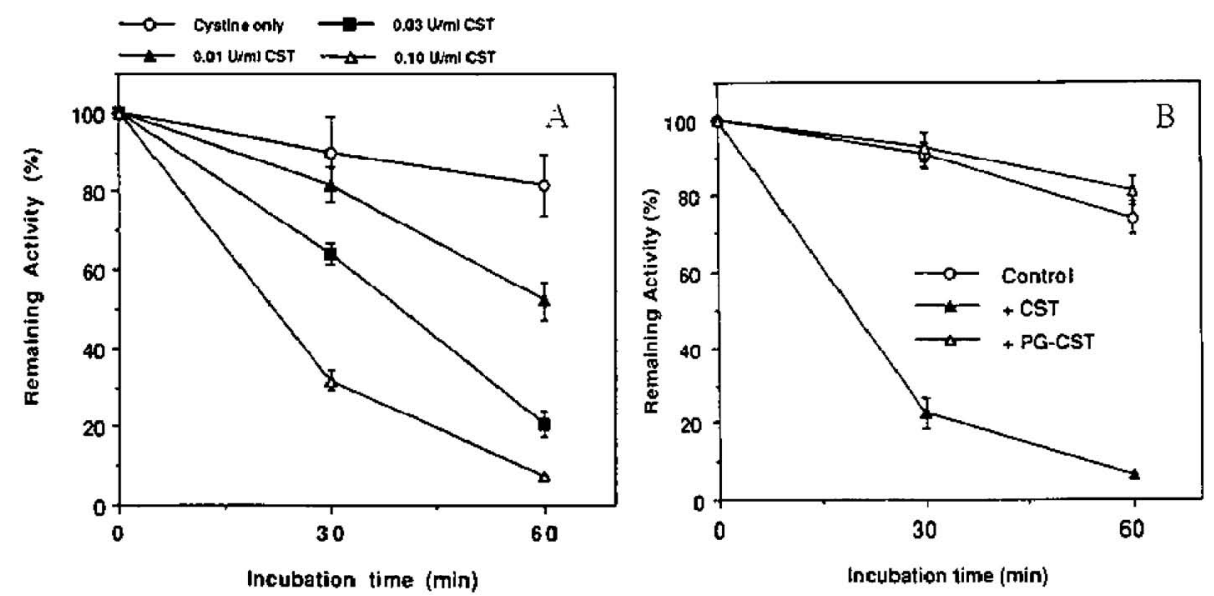

Fig. 7. Effects of $\gamma$-CST Concentration (A) and PG-pretreated $\gamma$-CST (B) on PFK Modification in Reconstitution System with Cystine

Incubations were carried out in PBS ( $\mathrm{pH} 7.4$ ), containing $0.25 \mathrm{~mm}$ ATP, $0.5 \mathrm{mM} \mathrm{Mg}^{2+}, 0.01 \% \mathrm{BSA}$, and $5 \mu \mathrm{g} / \mathrm{ml} \mathrm{PFK}$, (A): in presence of $0.05 \mathrm{~mm}$ cystine only (O), $0.05 \mathrm{~mm}$ cystine plus $0.01 \mathrm{U} / \mathrm{ml} \gamma$-CST $(\boldsymbol{\Delta}), 0.03 \mathrm{U} / \mathrm{ml} \gamma$-CST $(\boldsymbol{\square})$, or $0.10 \mathrm{U} / \mathrm{ml} \gamma$-CST $(\triangle)$ at $37^{\circ} \mathrm{C}$, (B) : in presence of $\gamma$-CST $(\boldsymbol{\Delta})$, PG-yreated $\gamma$ $\operatorname{CST}(\triangle)$, or none $(O)$. Percentage of activity was calculated based on initial activity before incubation. Values shown are means \pm S.D. for triplicate experiments.

疑問視されてきた。 Valentineらは, ${ }^{72)}$ ヒト赤血球 溶血液を非酵素的に PLP 存在下シスチンから生成 させた過硫化物や 3-MP で暴露すると，14 種の酵 素活性が阻害を受けることを報告している，これら の中には，PFK，PK 及び HK が含まれている。し かし，彼らは，用いた過硫化物生成系は極めて高濃 度のシスチンとPLPより構成されており，シスチ ンが直接的な交換反応により SH 酵素と混合ジスル フィドを形成していることも推測される．筆者らが 示した結合型イオウによる酵素活性修飾もジスルフ イド交換反応と同様，生体内の酸化還元のバランス に依存した調節と考えられるが，単なるジスルフィ ド交換反応よりも選択性を有し， $10 \mu \mathrm{M} レ$ レ゙ルの微 量な結合型イオウで鋭敏に反応する酵素の存在を明 らかにした。

4-5. 脂質過酸化と結合型イオウ チオール類 は細胞の酸化ストレスに対してラジカルスカベンジ ヤーとして働く. 結合型イオウの別の生理的作用と して，その還元状態に着目し，低分子と高分子結合 型イオウの活性酸素消去能について脂質過酸化の観 点から検討した。

4-5-1. 低分子結合型イオウによるラットシトク ロム P-450 依存脂質過酸化の防御低分子結合型 イオウとして比較的安定な trisulfide 誘導体を用い (Fig. 8), 肝ミクロゾームにおける脂質過酸化に対 する防御効果を, ラジカルスカベンジャーとしての 側面から，チオール，ジスルフィド化合物と比較検
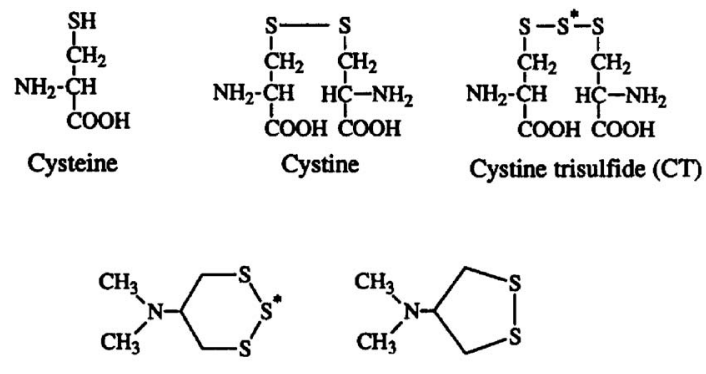

Thiocyclam (TC)

Nereistoxin (N'T)

Fig. 8. Trisulfide Derivatives and Reference Thiol and Disulfide Compound

*Bound sulfur.

討した. ${ }^{73)}$ 脂質過酸化は, $\mathrm{Fe}^{2+}$-ascorbic acid, $\mathrm{CCl}_{4}$, $t-\mathrm{BuOOH}$ と 3 つの系で行い, TBA 法で評価した. $\mathrm{CT}$ とチオシクラム（TC） は $\mathrm{CCl}_{4}, t-\mathrm{BuOOH}$ 系に よる脂質過酸化を, チオール, ジスルフィド化合物 より効果的に阻害したが，抗酸化効果は TC の方が CT よりも優れていた (Table 7)。 しかし, 非酵素 的な酸化ストレスを導く $\mathrm{Fe}^{2+}$-ascorbic acid 系に対 しは, trisulfide 類の防御効果は少なく, 特に TC は ほとんどその効果を示さなかった。この結果より， trisulfide 類はフリーラジカルに対して直接阻害効 果を示さず， cytochrome P-450 依存脂質過酸化を 阻害すると考えられる. Trisulfide 類の脂質過酸化 の防御効果を明確にするため, trisulfide 類存在下, cytochrome P-450 含量と cytochrome p-450 NADPH reductase 活性を測定した（Table 8). Trisulfide 類 
中の結合型イオウは $\mathrm{CCl}_{4}$ 及び $t-\mathrm{BuOOH}$ 系で誘導 されるラット肝臟ミクロソーム P-450 による脂質 過酸化を不活性化した。

Diethyldithiocarbamate（DDC）は生体内で二硫 化炭素に代謝され，さらに活性イオウ原子（結合型 イオウ）になり，ラットミクロソームの $\mathrm{CCl}_{4}$ - 誘導 脂質過酸化やマウス肝臓ミクロソームの NADPH誘導脂質過酸化を阻害する。 Trisulfide 類中の結合 型イオウも DDC と同じ機構で脂質過酸化を防御す ると考えられる。このように，生体内過酸化系に対 する結合型イオウの防御的効果を始めて示した. Trisulfide 類による処理は, cytochrome P-450 依存 脂質過酸化を効果的に阻害し，外来性異物や医薬品 の毒性を軽減させる効果がある。

\section{4-5-2. 高分子結合型イオウによるラット肝臓ミ} クロソームの脂質過酸化の抗酸化効果 生理的条 件では，ヒト血清中結合型イオウはすべて高分子画 分に存在し，その濃度は 0.5-3 $\mu \mathrm{M}$ と低濃度で, ${ }^{44)}$ 抗酸化物としての役割はあまり期待できない。しか し，前述したように肝臓や腎臟中には，かなり高濃

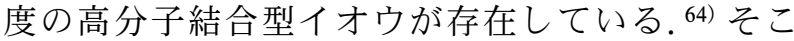
で，高分子結合型イオウのモデル化合物としてウシ SBA を用い，ラットミクロソームにおける脂質過 酸化の抑制効果を調べた. ${ }^{74)}$ 血清アルブミンは肝臟 で形成されたイオウを他の組織へ輸送する特異的キ ヤリヤーとして期待されている. ${ }^{75)}$ SBA は結合型イ オウ 3 原子と結合している，そのうちの 2 原子は未 荷電で，もう 1 つは荷電した過硫化体として存在し

Table 8. Effect of Bound Sulfur in Trisulfide Derivatives and SBA, and Reference Compounds on Lipid Peroxidation Relative Enzymes in Rat Liver Microsomes

\begin{tabular}{lcc}
\hline \hline & \multicolumn{2}{c}{ Recovery $(\%)^{a)}$} \\
\cline { 2 - 3 } & $\begin{array}{c}\text { Cytochrome } \\
\text { P-450 }\end{array}$ & $\begin{array}{c}\text { NADPH Cyt. } \\
\text { P-450 Red }\end{array}$ \\
\hline None & 100 & 100 \\
Thiocyclam & 32.8 & 82.2 \\
Nereistoxin & 87.5 & 102.2 \\
Cystine trisulfide & 55.9 & 88.0 \\
Cysteine & 93.7 & 100.7 \\
Cystine trisulfide & 85.0 & 96.4 \\
SBA $^{c}$ & 32.8 & 82.2 \\
BSA $^{d)}$ & 87.5 & 102.2 \\
\hline
\end{tabular}

a) Values are relative to control $(=100)$ and reported as means from two independent experiments. $b$ ) NADPH cytochrome P-450 reductase. c) $2.3 \mathrm{mg}$ albumin $/ \mathrm{ml}(100 \mu \mathrm{M}$ as bound sulfur).d) $2.3 \mathrm{mg}$ albumin $/ \mathrm{ml}$.
ている.アルブミンの唯一の遊離チオールである Cys-34 はシステインやグルタチオンの結合位置 で, チオール交換によって過硫化体 $\left[\mathrm{Alb}\left({ }^{34} \mathrm{Cys}\right)\right.$ $\mathrm{S}^{-} \mathrm{S}^{-}$] を取る. SBA のラット肝臓ミクロゾームに おける抗脂質過酸化効果は，低分子結合型イオウの 場合と同様に，非酵素的誘導系である $\mathrm{Fe}^{2+}$-ascorbic acid 系と, 酵素的誘導系である $\mathrm{CCl}_{4}$ と $t$ $\mathrm{BuOOH}$ 系の 3 つの系で行い, ウシ BSA と比較し た。また，ポジテブコントロールとして $\alpha$-Tocopherolを用いた（Table 9）。

$\mathrm{Fe}^{2+}$-ascorbic acid に対する抗酸化作用は， $\alpha$ Tocophenol と BSA では差がないが，SBAは3つ の脂質過酸化誘導系に対して濃度依存的に抑制し た。また，ラット肝臓ミクロソーム懸濁液を用いた 脂質過酸化による酸素消費速度は, $t$ - $\mathrm{BuOOH}, \mathrm{Fe}^{2+}$ 一 ascorbic acid 系で SBA は減少させたが, BSA は $t$ $\mathrm{BuOOH}$ 系で増加傾向にあり, $\mathrm{Fe}^{2+}$-ascoribic acid 系においてはほとんど影響がなかった。また， SBA 中の結合型イオウの減少は, $\mathrm{Fe}^{2+}$-ascorbic acid 系で増強された。 $\mathrm{CCl}_{4}$ 及び $t-\mathrm{BuOOH}$ 系から のフリーラジカルに関係する酵素系に対する SBA の効果を Table 8 に示す. SBA 中の結合型イオウ は低分子型と同様に, 肝臓ミクロゾーム cytochrome P-450 を分解する. Cytochroe P-450 と 結合型イオウの相互作用の詳細はまだはっきりして いないが，結合型イオウはすみやかに cytochrome P-450 と反応し分解する. また，どの型のタンパク 質-結合型イオウが非酵素的な脂質過酸化に対する 防御効果を示すか興味深いところである.

\section{5. おわりに}

以上，筆者らは無機陰イオン，特に含硫無機化合

Table 9. Inhibitory Effects of SBA on Lipid Peroxidation Induced by Various Systems

\begin{tabular}{lccr}
\hline \hline \multirow{2}{*}{$\begin{array}{c}\text { Induced } \\
\text { systems }\end{array}$} & \multicolumn{3}{c}{ Inhibition (\%) } \\
\cline { 2 - 4 } & $\alpha$-Tocopherol $^{b)}$ & SBA $^{c}$ & \multicolumn{1}{c}{ BSA $^{d)}$} \\
\hline $\mathrm{Fe}^{2+}$-Asc & $8.1 \pm 5.46$ & $13.8 \pm 7.80$ & $7.9 \pm 4.78$ \\
$\mathrm{CCl} 4$ & $7.7 \pm 3.59^{\ddagger}$ & $22.1 \pm 6.11^{\sharp}$ & $-8.5 \pm 0.98$ \\
$t$-BuOOH & $29.6 \pm 1.93^{\sharp}$ & $18.2 \pm 4.64^{\sharp}$ & $-4.4 \pm 2.48$
\end{tabular}

Lipid peroxidation was determined by TBA-RS test. Values are presented as means \pm S.D. from three independent experiments. a) Inhibition $(\%)=($ control-sample $/$ control-blank $) \times 100$, control: without sample, blank: without inducer and sample, b) $50 \mu \mathrm{M}, c) 2.3 \mathrm{mg}$ albumin $/ \mathrm{ml}(100$ $\mu \mathrm{M}$ as bound sulfur), d) $2.3 \mathrm{mg}$ albumin $/ \mathrm{ml}$. " Significantly different from the value of BSA, $p<0.01$ 
物について生体中での微量分析法，スルファンイオ ウで代表される結合型イオウの測定法と存在意義に ついて述べた．生体中は，いろいろな形のイオウが 存在し，鉄一イオウクラスターで代表される生命に 不可欠な構成成分となっている。ここで記した研究 は，千葉大学での 5 年間と明治薬科大学に移っての 約 10 年間で行ったもので, 現在からみると約 10 年 の歳月がたっている。脳には高濃度の硫化物イオン が存在している。それに注目した硫化水素の生理的 意義に関する研究が最近活発に行われている，毒性 のある硫化水素の別な側面として興味がもたれる。

\section{謝辞これまでの私の研究を支えて頂きまし} た, 千葉大学薬学部（故）坂口武一名誉教授, 本総 説における最初の研究を指導して頂きました今成登 志男名誉教授，当時研究をともに行った戸井田敏彦 教授及び大学院，卒研生の皆さんに深謝いたしま す。明治薬科大学に移ってからは，川鍋康治名誉教 授，研究体制づくりと研究に苦楽をともにした鬼川 忠靖准教授，石井一行准教授，小笠原裕樹講師，鈴 木俊宏助教, 縄田正志元助手及び分析化学教室, 衛 生化学教室（現環境生体学教室）大学院，卒研生の 皆さんに心から感謝いたします。ここに記した内容 は，筆者ら研究グループの成果の一部ですが，みな さんが切磋环磨して得た研究成果であることを記さ せて頂きます。

\section{REFERENCES}

1) Griffith O. W., "Methods in Enzymology," eds. by Jakoby W.B., Griffith O.W., Academic Press, San Diego, 1987, pp. 366-376.

2) de la Rosa J., Drake M. R., Stipanuk M. H., J. Nutr., 117, 549-558 (1986).

3) Drake M. R., de la Rosa J., Stipanuk M. H., Biochem. J., 244, 279-286 (1987).

4) Sörbo B., "Metabolism Pathways, 3rd ed., Vol. VII, Sulfur Compounds" ed. by Greenberg D. M., Academic Press, New York, 1975, pp. 433-456.

5) Stipanuk M. H., Annu. Rev. Nutr., 6, 179209 (1986)

6) Westley J., Adv. Enzymol., 39, 327-368 (1973)

7) Westley J., "Enzymatic Basis of Detoxication,
Vol. 2, Rodanese and the Sulfane Pool in Enzymatic Basis of Detoxication' ed. by Jacoby W. B., Academic Press, New York, 1980, pp. 245-260.

8) Schneider J. F., Westley J., J. Biol. Chem., 244, 5735-5744 (1969).

9) Tanabe S., Toida T., Ogata K., Taguchi K., Imanari T., Bunseki Kagaku, 30, 31-35 (1981).

10) Waheed A., VanEtten R. L., Anal. Biochem., 89, 550-560 (1978).

11) Tanabe S., Toida T., Imanari T., Ookubo N., Miyazaki M., Bunseki Kagaku, 29, 543-547 (1980).

12) Butts W. C., Kuehneman M., Clin. Chem., 20, 1344-1348 (1974).

13) Lundquist P., Martensson J., Sörbo B., Ohman S., Clin. Chem., 25, 678-681 (1979).

14) Mudd S. H., Irrevere F., Laster L., Science, 156, 1599-1602 (1967).

15) Toida T., Ogata K., Tanabe S., Imanari T., Bunseki Kagaku, 29, 764-768 (1980).

16) Imanari T., Tanabe S., Toida T., Kawanishi T., J. Chromatogr., 250, 55-61 (1982).

17) Imanari T., Ogata K., Tanabe S., Toida T., Kawanishi T., Ichikawa M., Chem. Pharm. Bull., 30, 374-375 (1982).

18) Kagedal B., Kallberg M., Martensson J., Sörbo B., J. Chromatogr., 274, 95-102 (1983).

19) Kawanishi T., Togawa T., Ishigami A., Tanabe S., Imanari T., Bunseki Kagaku, 33, E295-E300 (1984).

20） Lee S. H., Field L. R., Anal. Chem., 56, 26472653 (1984).

21) Tanabe S., Kitahara M., Nawata M., Kawanabe K., J. Chromatogr. B, 424, 29-37 (1988).

22) Imanari T., Tanabe S., Toida T., Chem. Pharm. Bull., 30, 3800-3802 (1982).

23) Funazo K., Tanaka M., Shono T., Anal. Chem., 53, 1377-1380 (1981).

24) Toida T., Tanabe S., Imanari T., Chem. Pharm. Bull., 29, 3763-3764 (1981).

25) Toida T., Togawa T., Tanabe S., Imanari T., J. Chromatogr. B, 308, 133-141 (1984).

26) Shea M., Howell S., Anal. Biochem., 140, 589594 (1984).

27) Togawa T., Ogawa M., Nawata M., 
Ogasawara Y., Kawanabe K., Tanabe S., Chem. Pharm. Bull., 40, 3000-3004 (1992).

28) Togawa T., Tanabe S., Kato M., Koshiishi I., Toida T., Imanari T., J. Pharmacobio-Dyn., 13, 83-89 (1990).

29) Togawa T., Akiyama Y., Kaneko K., Nakamura A., Imanari T., Anal. Sci., 2, 477480 (1986).

30) Togawa T., Ohsawa A., Kawanabe K., Tanabe S., J. Chromatogr., B, 704, 83-88 (1997).

31) Ida S., Kuriyama K., Anal. Biochem., 130, 95 -101 (1983).

32) Hirschberger L. L., de la Rosa J., Stipanuk M. H., J. Chromatogr., 343, 303-313 (1985).

33) Savage J. C., Gould D. H., J. Chromatogr., 526, 540-545 (1990).

34) Mitchell T. W., Savage J. C., Gould D. H., J. Appl. Toxicol., 13, 389-394 (1993).

35) Goodwin L. R., Francom D., Dieken F. P., Taylor J. D., Warenycia M. W., Reiffenstein R. J., Dowling G., J. Anal. Toxicol., 13, 105109 (1989).

36) Hannestad U., Margheri S., Sörbo B., Anal. Biochem., 178, 394-398 (1989).

37) Yamamoto Y., Umeda M., Morishige K., Nishikawa Y., Bunseki Kagaku, 37, 421-425 (1988)

38) Ogasawara Y., Ishii K., Togawa T., Tanabe S., Analyst, 116, 1359-1363 (1991).

39) Ogasawara Y., Ishii K., Togawa T., Tanabe S., Anal. Biochem., 215, 73-81 (1993).

40) Westley A. M., Westley J., Anal. Biochem., 195, 63-67 (1991).

41) Meister A., Fed. Proc., 12, 245 (1953).

42) Nagahara N., Okazaki T., Nishino T., J. Biol. Chem., 270, 16230-16235 (1995).

43) Aita N., Ishii K., Atamatsu Y., Ogasawara Y., Tanabe S., Biochem. Biophys. Res. Commun., 231, 56-60 (1997)

44) Taniguchi T., Kimura T., Biochim. Biophys. Acta, 364, 284-295 (1974).

45) Nishino T., Adv. Exp. Med. Biol., 195b, 259262 (1985).

46) Jarabak R., Westley J., Arch. Biochem. Biophys., 185, 458-465 (1978).

47) Valentine W. N., Frankenfeld J. K., Clin. Chim. Acta, 51, 205-210 (1974).

48) Vachek H., Wood J. L., Biochem. Biophys.
Acta, 258, 133-146 (1972).

49) Kun E., Biochim. Biophys. Acta, 25, 135-137 (1957).

50) Jackson J. F., Smith T. M., Biochim. Biophys. Acta, 121, 159 (1966).

51) Tanabe S., Ogasawara Y., Nawata M., Kawanabe K., Chem. Pharm. Bull., 37, 28432845 (1989).

52) Nawata M., Ogasawara Y., Kawanabe K., Tanabe S., Anal. Biochem., 190, 84-87 (1990)

53) Nagahara N., Ito T., Kitamura H., Nishino T., Histochem. Cell Biol., 110, 243-250 (1998)

54) Nagahara N., Ito T., Minami M., Histol. Histopathol., 14, 1277-1286 (1999).

55) Leber T., Graefes Arch. Ophthalmol., 2, 249291 (1871).

56) Sörbo B., Acta Chem. Scand., 7, 1129-1136 (1953).

57) Cannella C., Berni R., Ricci G., Anal. Biochem., 142, 159-162 (1984).

58) Nawata M., Yagi T., Kawanabe K., Tanabe S., Chem. Pharm. Bull., 39, 3279-3282 (1991).

59) Matsuo Y., Greenberg D. M., J. Biol. Chem., 230, 545-559 (1958).

60) Matsuo Y., Greenberg D. M., J. Biol. Chem., 230, 545-559 (1958).

61) Viña J., Vento M., Garcia-Sla F., Puertes I. R., Gascó E., Sastre J., Asensi M., Pallardó F. V., Am. J. Clin. Nutr., 61, 1067-1069 (1995)

62) Ohmori S., Nakata K., Nishihara K., Yamamoto S., Kawase M., Tsuboi S., J. Chromatogr., B, 574, 35-40 (1992).

63) Ogasawara Y., Ishii K., Tanabe S., J. Biochem. Biophys. Methods, 51, 139-150 (2000).

64) Ogasawara Y., Isoda S., Tanabe S., Biol. Pharm. Bull., 17, 1535-1542 (1994).

65) Ziegler D. M., Annu. Rev. Biochem., 54, 305329 (1985).

66) Westley J., Adler H., Westley L., Nishida C., Fundam. Appl. Toxicol., 3, 377-382 (1983).

67) Ogata K., Xing D., Volini M., J. Biol. Chem., 264, 2718-2725 (1989).

68) Ogasawara Y., Isoda S., Tanabe S., Biol. Pharm. Bull., 18, 1045-1048 (1995). 
69) Cerletti P., Trends Biochem. Sci., 11, 369-372 (1986).

70) Ogasawara Y., Suzuki T., Ishii K., Tanabe S., Biochim. Biophys. Acta, 1334, 33-43 (1997).

71) Holmgren A., Åslund F., Methods Enzymol., 252, 199-208, 283-292 (1995).

72) Valentine W. N., Toohey J. I., Paglia D. E., Nakatani M., Brockway R. A., Proc. Natl.
Acad. Sci. U.S.A., 84, 1394-1398(1987).

73) Ogasawara Y., Isoda S., Tanabe S., Toxicol. Lett., 99, 191-198 (1998).

74) Ogasawara Y., Isoda S., Tanabe S., Biol. Pharm. Bull., 22, 441-445 (1999).

75) Jarabak R., Westley J., J. Biochem. Toxicol., 5, 1-8 (1990). 